\title{
Bonding efficiency and durability: current possibilities
}

\section{Adriana Bona MATOS(a) \\ Livia Tosi TREVELIN(a) \\ Beatriz Togoro Ferreira da SILVA(a) Luciana Fávaro \\ FRANCISCONI-DOS-RIOS(a) \\ Luciana Kfouri SIRIANI(a) \\ Marcio Vivan CARDOSO(b)}

(a) Universidade de São Paulo - USP, School of Dentistry, Department of Operative Dentistry, São Paulo, SP, Brazil.

(b)GC Europe N.V., Professional Services Manager, Scientific Affairs, Leuven, Belgium.
Abstract: Bonding plays a major role in dentistry nowadays. Dental adhesives are used in association with composites to solve many restorative issues. However, the wide variety of bonding agents currently available makes it difficult for clinicians to choose the best alternative in terms of material and technique, especially when different clinical situations are considered. Moreover, although bonding agents allow for a more conservative restorative approach, achieving a durable adhesive interface remains a matter of concern, and this mainly due to degradation of the bonding complex in the challenging oral environment. This review aims to present strategies that are being used or those still in development which may help to prevent degradation. It is fundamental that professionals are aware of these strategies to counteract degradation as much as possible. None of them are efficient to completely solve this problem, but they certainly represent reasonable alternatives to increase the lifetime of adhesive restorations.

Keywords: Dentin-Bonding Agents; Dental Cements; Adhesives; Dental Enamel.

\section{Introduction}

Declaration of Interests: The authors certify that they have no commercial or associative interest that represents a conflict of interest in connection with the manuscript.

Corresponding Author:

Adriana Bona Matos

E-mail: bona@usp.br

htips://doi.org/10.1590/1807-3107BOR-2017.vol31.0057

Submitted: May 12, 2017

Accepted for publication: May 22, 2017

Last revision: May 25, 2017
The advent of adhesives and the understanding of their interaction mainly with dentin have recognizably become landmarks for the practice of operative and conservative dentistry. In addition to direct resin restorations of teeth compromised by fractures, carious or non-carious lesions, adhesives enable several other procedures, such as bonding of indirect restorations, intra radicular posts and orthodontic brackets, repair of failed restorations, control of dentin hypersensitivity and correction of aesthetic impairments.

For a long time, amalgam was the material of choice for directly restoring posterior damaged teeth, leading to the preparation of large and geometric macro-retentive cavities. However, as recently presented by Alexander et al., ${ }^{1}$ the United Nations Environment Programme (UNEP), supported by the World Health Organization (WHO), has urged for policies that could play down the use of mercury, and consequently of dental amalgam. This trend was also corroborated by the Minamata Convention, which strengthened the so-called phase-down of amalgam. ${ }^{2}$ Despite many controversies about its suitability as a real alternative to amalgam, resin composites gradually turned out to be the most indicated restorative material, also for posterior 
teeth. This procedure, however, always requires an intermediate bonding agent which penetrates enamel and/or dentin, primarily establishing what is called micromechanical bonding. ${ }^{3}$ Basically, the adhesive procedure consists of removing minerals from the dental substrate by acid etching it to create micro-retentive porosities, where resin monomers infiltrate and polymerize. ${ }^{4,5,6}$ Specifically, on dentin, the acid etching procedure not only removes possible superficial debris, the so-called smear layer, but also exposes a net of collagen fibers besides opening the dentin tubules. By penetrating this collagen mesh and dentin tubules, the infiltrating resin will form two welldefined structures which are known as hybrid layer and resin tags, respectively. This polymer-collagen biocomposite layer is in large part responsible for the bonding effectiveness, which does not actually rely on its thickness but rather on its quality. ${ }^{7}$ In other words, an effective bonding relies mostly on the ability of the bonding agent to completely infiltrate the exposed collagen mesh, ideally sealing and protecting it from all sorts of degradation pathways. In the same way, it has been suggested that the bonding effectiveness does not depend on the number nor on the length of resin tags. ${ }^{7}$

Contemporary adhesives are formally categorized into two main types according to their mechanism of action, namely etch-and-rinse and self-etch systems. ${ }^{4,5,8}$ The first requires prior application of phosphoric acid as an initial step. After mandatory rinsing, smear layer is completely removed and the tooth substrate is demineralized, resulting in profound pores in the highly-mineralized enamel and exposed collagen mesh in dentin in a depth that may range from $5 \mu \mathrm{m}$ to $10 \mu \mathrm{m} .{ }^{4,5,9,10}$ When using etch-and-rinse systems, proper hybrid layer is classically achieved through the infiltration of resin monomers into the exposed collagen mesh by using the so-called wet-bonding technique. In this protocol, water remaining from the rinsing step maintains the collagen network expanded, allowing resin monomers to properly infiltrate it; excessive dehydration would cause fibrils to collapse, impairing resin penetration and hybrid layer formation. ${ }^{11,12,13}$ However, it is noteworthy that the wet-bonding technique is a major challenge for clinicians, who do not count on ultimate parameters to determine ideal moisture. Although it is suggested that dentin should clinically present a shiny aspect, this judgement is subjective and not precise enough. ${ }^{11,12}$ Etch-and-rinse adhesives are subcategorized according to their presentation, more specifically according to the number of steps needed to accomplish the adhesive protocol. Three-step systems are comprised of etchant, primer and bonding resin while their two-step counterparts consist of etchant and a single bottle containing both primer bonding resin chemical components. ${ }^{14}$ Primers contain water, ethanol, and/or acetone as solvents which act dissolving hydrophilic monomers such as HEMA, for example. While chasing water from the wet tooth substrate, they prevent collagen network from collapsing, therefore allowing for proper impregnation of the solvent-free, hydrophobic bonding resin. ${ }^{4,6}$

Conversely, self-etch adhesives contain monomer molecules with carboxylate or phosphate acidic groups which concurrently etch and infiltrate dental substrates in such a manner that smear layer is not removed, but incorporated into the adhesive interface. ${ }^{5,15,16}$ Even if the thickness of demineralization/impregnation area is smaller than that promoted by etch-and-rinse adhesives, this does not necessarily reflect on lower bond strength. ${ }^{16}$ Self-etch adhesives differ from each other in the amount of intrinsic water and potential of hydrogen $(\mathrm{pH}) \cdot{ }^{17}$ Their formulation is available in one or two separate bottles/compartments and their application protocol can be carried out in one or two steps. Both presentations can be subdivided according to their acidity into 'strong' ( $\mathrm{pH} \leq 1)$, 'intermediate' $(\mathrm{pH} \approx 1.5)$,' mild' $(\mathrm{pH} \approx 2)$ and 'ultra-mild' $(\mathrm{pH} \geq 2.5) .^{5}$ Those having a $\mathrm{pH}$ lower than or near to 1.5 , contain functional monomers which mainly demineralize dental hard tissues instead of chemically bonding to hydroxyapatite; those having a $\mathrm{pH}$ greater than 1.5, only demineralize the dental substrate partially, chemically interacting with the remaining hydroxyapatite. ${ }^{5}$ The latter thus only exposes dentin collagen very superficially, creating a nanoscaled hybrid layer also referred to as nano-interdiffusion zone. ${ }^{18}$ Higher bonding durability obtained with these "mild" self-etch bonding agents can be ascribed, among other aspects, to the formation of a rather thin hybrid layer which is less prone to hydrolysis. 
Partial demineralization of dentin and consequent bonding to remaining hydroxyapatite also counts for a more stable and durable bonding interface. ${ }^{5,19}$ Such interaction is derived from the presence of specific functional monomers in the adhesive composition: 10-methacryloyloxydecyl dihydrogen phosphate (10-MDP), 4-methacryloyloxyethyl trimellitate anhydride (4-META) and 2-metacriloxil ethyl phenyl hydrogen phosphate (Phenyl-P). ${ }^{20}$

A new family of adhesives, named "universal" or "multi-mode", was recently introduced in the dental market aiming for further simplification of the adhesive procedure and rationalization of the inventory at the dental office. ${ }^{21}$ The definition of a universal bonding agent is still controversial. Although many commercially available brands claim their universality, a real "multi-mode" adhesive should: a) perform equally well in both etching modes (etch-and-rinse and self-etch); b) bond to enamel and dentin as well as to different restorative materials (composites, ceramics, metal, zirconia, and so on); and c) be suitable for use in both direct and indirect restorative techniques irrespective of the curing mode of the luting cement (light-cure or dual-cure). Despite their versatility in terms of etching mode (etch-andrinse or self-etch ${ }^{21,22}$ such adhesives are essentially single-step self-etch bonding agents. Some of them contain copolymers of polyalkenoic acid which, in combination with MDP, show contradictory results regarding their bonding effectiveness. ${ }^{23,24}$ Considering the concept of "multi-mode application", one must assume that bond strength would not be compromised by the chosen etching strategy. However, it has been noticed that enamel etching with phosphoric acid favors the bonding performance of these bonding agents. ${ }^{17}$ For dentin, similar immediate performance was observed regardless of the application mode, but significant reduction in bond strength to dentin, both in dry and wet-bonding techniques, was reported in the long-term when phosphoric acid was used..$^{22}$ It has been suggested that phosphoric acid demineralizes dentin in a greater depth than self-etch adhesive systems can infiltrate. Moreover, the adhesive interface will not benefit from the advantages of chemical bonding in case the dentin surface is extensively demineralized and residual apatite crystals are not left in sufficient amount to promote the desirable interaction with the adhesive's functional monomers. ${ }^{25,26}$ Finally, post-operative sensitivity is less likely to occur when the self-etch protocol is adopted..$^{22,27}$

As another restorative alternative, glass-ionomers are self-adhering materials that can bond to tooth structure without an intermediate adhesive layer. ${ }^{5,28,29}$ However, a short polyalkenoic acid pre-treatment is recommended, resulting in a two-step approach. Such acidic conditioner removes the smear layer and demineralizes the underlying dentin up to a depth of about $0.5-1 \mu \mathrm{m} .{ }^{30}$ Glass ionomer components are then able to infiltrate the exposed collagen mesh, establishing a micro-mechanical retention which follows the principle of hybridization. ${ }^{31}$ Within this hybrid layer, a chemical bonding is also obtained by ionic interaction of the carboxyl groups of the polyalkenoic acid with calcium of hydroxyapatite that remains attached to the collagen fibrils. ${ }^{20}$ This two-fold bonding mechanism which combines micromechanical interlocking and chemical interaction may explain the clinical success boasted by glass ionomers in specific clinical indications such as nonstress bearing restoration $\mathrm{s}^{28}$ and atraumatic restorative treatment. ${ }^{32}$ Likewise, mild self-etch adhesives, the chemical bonding promoted by glass ionomers has also been described as an important aspect against hydrolytic degradation of the adhesive interface., ${ }^{5,28}$ Despite its excellent clinical performance in terms of retention and microleakage in non-stress bearing areas, glass ionomers commonly present lower aesthetic characteristics and polishing maintenance over time due to their lower mechanical properties when compared to resin-based restorative materials. ${ }^{33}$ Nevertheless, a modern high-viscosity glass ionomer associated with a resin-based protective coating has been showing promising clinical performance in posterior permanent restorations, ${ }^{34,35}$ therefore deserving further attention.

Dental adhesive technology, as impeccably stressed

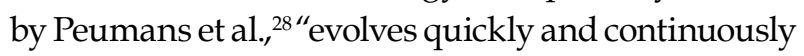
with a rapid turnover of commercial adhesives, a high number of laboratory studies on adhesive materials and a high demand for laboratory techniques and data in potential prediction of clinical effectiveness". Despite the importance of laboratory studies, clinical trials 
remain the ultimate source to collect scientific data on the effectiveness of different restorative materials and protocols. All things considered, the practice of restorative dentistry should base itself on qualified evidence-based dentistry to better understand the intrinsic limitations of current restorative materials, especially those of bonding agents, aiming to overcome them in favor of a successful clinical performance.

The key to success in adhesive dentistry relies on the effectiveness of the adhesive interfaces over time. By developing new restorative products and operative strategies, one can increase the long-term performance of aesthetic restorations, thus minimizing the need for replacement of failed restorations in the daily clinical practice. This review aims to explain the mechanisms of degradation of adhesive interfaces, suggesting strategies to overcome the intrinsic limitations of bonding agents and their application protocols.

\section{Why do adhesive interfaces fail?}

Sano $^{36}$ hypothesized that the biodegradation of the adhesive interface involves a sequence of events. The first stage towards biodegradation starts when dentin is acid etched for smear layer removal and exposure of the underlying collagen network for subsequent hybrid layer formation. Once depleted of minerals, the exposed collagen fibers become more prone to prospective deterioration. In the second stage, resins that infiltrated the dentin matrix are leached out and replaced by water creating nanometer-sized voids within the hybrid layer. The third stage involves enzymatic degradation of the exposed collagen fibrils. During bonding procedures with both etch-and-rinse and self-etch systems, demineralized dentin activates proteolytic enzymes (MMPs) that are also responsible for the degradation of unprotected collagen fibrils. ${ }^{37,38}$ Therefore, we might need to counteract the adverse effects of enzymes such as esterases and matrix metalloproteinases (MMPs) at the bonding interface.

If biodegradation of the adhesive interface is to be avoided, a complete and intimate infiltration of resin monomers into the collagen network is fundamental, as well as an efficient polymerization of these monomers in situ. Both goals are clear and reasonable, but not so easily attained.
Acid etching of dentin removes its inorganic components, exposing collagen fibrils which should be subsequently protected through an intimate and complete infiltration of resin monomers from the bonding agent. However, the depth of demineralization can be greater than the infiltrating potential of resin monomers, leaving a zone of unprotected collagen fibers. This area is highly vulnerable to both hydrolytic and enzymatic degradation. ${ }^{6}$ For the adhesives to properly impregnate its hydrophobic monomers into the intrinsically humid dentin, hydrophilic monomers are included in their composition. As a counter effect, the adhesive interface becomes more prone to water sorption and consequent hydrolysis ${ }^{39,40,41,42,43,44}$ Hydrophilic adhesives can also attract water from hydrated dentin resulting in water-filled channels within the polymer matrices. ${ }^{45}$ Besides promoting the degradation of collagen fibers, water also presents a degradative effect on resin monomers. Most of the monomers used in bonding agents nowadays do contain chemical groups such as ester, urethane and hydroxyl groups and ether linkages that are susceptible to hydrolytic cleavage. Water within the adhesive layer is therefore also responsible for the elution of unreacted monomers within the adhesive layer ${ }^{46}$ and plasticization of the polymer network. ${ }^{47}$ Porosity and intermolecular spaces in the polymer network further contributes for the degradation of the hybrid layer due to hydrolysis or exposure of additional collagen fibrils to activated MMPs. ${ }^{48}$

Interaction between polymeric dental materials and dentin organic components seems to be rather complex from a sub-micrometer perspective, therefore impairing a hermetic encapsulation of dentin collagen fibrils. According to its structural relation with collagen, hydroxyapatite in dentin can be classified into extrafibrillar mineral, located among the fibrils, and intrafibrillar mineral, mainly in the gaps within the fibrils extending between collagen molecules. ${ }^{49}$ The synthetic monomers used nowadays are meant to infiltrate the space among collagen fibrils. Nevertheless, they do not seem to be small enough to penetrate the nanometric voids between collagen molecules within the demineralized collagen fibers..$^{50}$ Moreover, it has been shown that collagen molecules are surrounded by water molecules to form highly 
ordered and multilayered cylinders of hydration ${ }^{51}$ which may favor the hydrolytic degradation of resin monomers in a sub-micrometer level.

To reduce the degradation process detailed above, some recent strategies can be explored, such as: inactivation or blockage of MMP's; reduction of dentin water content without increasing hydrophilic components of adhesive systems; addition of new chemical functional monomers into bonding agents; and an increase of collagen fibers stiffness to improving their resistance.

\section{Strategies to counteract degradation of adhesive interfaces}

\section{Caries management from the restorative point of view}

Minimal intervention approach recommends complete removal of infected dentin and maintenance of caries-affected dentin (CAD) on the pulpal cavity floor. Although most the literature related to the performance of bonding agents refers to sound dentin as a standard substrate ${ }^{52}$ clinicians are frequently challenged by the presence of caries-affected and/or sclerotic dentin in their daily practice. In the same way, manufacturers base their new technologies on the adhesion to sound dentin which is far from representing a clinically relevant substrate. The main common goal among researchers and manufacturers should be the development of a bonding agent that could equally bond to sound, cariesaffected, eroded and sclerotic dentin. ${ }^{53}$

The caries process induces different chemical, biological and physical modifications on the affected substrate, rendering it less favorable for interaction with polymeric restorative materials..$^{54}$ Bonding to infected dentin is contra-indicated due to its high bacterial count, lower resistance due to high minerals loss, and advanced deterioration of collagen structure. Consequently, such substrate should be completely removed. ${ }^{55}$ Caries-affected dentin, in turn, is more permeable than sound dentin due to its lower mineral content, besides presenting a higher water ratio and important changes in the secondary structure of collagen. ${ }^{54}$ Despite these unfavorable features, CAD still stands high chances of remineralization, which justifies its maintenance at the pulpal floor of the cavity. It should be considered, however, that a hybrid layer of poorer quality is obtained on $C A D$, and that a lower bonding performance may be expected irrespective of the kind of bonding agent employed. ${ }^{56}$

While manufacturers do not create an adhesive system that performs equally well on different sorts of modified dentin, it is highly recommended to finish the margins of the restoration in sound tooth structure to assure an optimal marginal sealing. ${ }^{56}$ In the light of a more conservative approach, caries-affected dentin should be maintained at the pulpal cavity floor and should be covered with a thin layer of glass ionomer cement. There are indications that glass ionomer cements may promote remineralization of caries affected dentin, ${ }^{57}$ although further studies are necessary to evaluate the reincorporation of mineral content within demineralized dentin and the recovery of its mechanical properties. The bonding agent must be applied over the remaining cavity walls and margins after application of the glass ionomer cement as part of the procedure for adhesive composite restorations.

\section{Chemical bonding}

Chemical bond in SE adhesives is achieved through specific functional monomers that bind calcium ions of hydroxiapatite within the hybrid layer. ${ }^{5,58}$ Different functional monomers may be found in this kind of bonding agents such as 10- methacryloyloxydecyl dihydrogen phosphate (10 MDP), 4- methacryloxyethyl trimellitic acid (4-MET) and 2 (methacryloyloxyethyl) and phenyl hydrogenphosphate (Phenyl-P). ${ }^{5,58}$ Their physico-chemical properties play an important role on the bonding effectiveness and durability of self-etch adhesives. ${ }^{5,59}$

Such chemical bond is mostly observed in mild and ultra-mild SE adhesives $(\mathrm{pH}<2)$ that partially demineralizes dentin producing sub-micrometer hybrid layers ${ }^{14}$ in which substantial HAp-crystals remain around partially exposed collagen fibers. ${ }^{3,18,60,61}$ Besides protecting collagen fibers against degradation, such remaining mineral content also serves as receptor for additional chemical bonding with the respective functional monomer, ${ }^{14,18}$ by which their two-fold bonding mechanism (i.e. micro-mechanical and chemical adhesion) closely resembles that of glass-ionomers. ${ }^{62}$ 
The additional chemical bonding of mild self-etch adhesives and glass-ionomers is supposed to be beneficial in terms of bonding durability. ${ }^{18,20}$ However, the ability to chemically bond to HAp is not sufficient on its own. The formed ionic bond should also be stable in an aqueous environment. It has been demonstrated that the chemical bonding generated by 10-MDP is not only more effective, but also more stable in water than that of 4-MET and phenyl-P. ${ }^{18}$ The dissolution rate of the calcium salts formed by these three monomers was inversely related to their chemical bonding potential. This chemical phenomenon is known as the adhesion-decalcification concept (AD-concept) that defines if molecules will either decalcify or adhere to mineralized tissues. ${ }^{63}$ The more effective bonding promoted by 10-MDPcontaining adhesives has recently been demonstrated via bond strength tests. ${ }^{64}$ From a chemical point of view, the ionic interaction of 10-MDP with HAp has been revealed by $\mathrm{X}$-ray diffraction (XRD) complemented by Transmission Electron Microscopy (TEM), presenting it as a "nanolayered" structure at the tooth-adhesive interface, and this being more evidently observed on dentin than on enamel. ${ }^{64}$ Each layer of this self-assembled nano-layered structure constitutes of two 10-MDP molecules with their methacrylate groups directed towards each other and their functional hydrogen phosphate groups directed away from each other. In between the layers, calcium salts are deposited ${ }^{65}$

Apparently, the weakest zone in self-etch adhesives is located below the hybrid layer, where the adhesive penetration and/or polymerization are not sufficient to protect collagen against hydrolysis and enzymatic degradation. ${ }^{6,66,67,68}$ Despite its superior performance as compared to other functional acidic monomers, the salt formed by 10-MDP may also degrade with time, as it is also somehow sensitive to hydrolytic dissolution. ${ }^{61}$ According to Kim et al. ${ }^{67}$ the hydrolytic degradation of the collagen fibers still occurs at the base of the hybrid layer, characterized by voids and nanoleakage between the intact top of the hybrid layer and the mineralized dentin base, as detected by SEM and Confocal microscopy analysis.

Considering the chemical bonding approach, a strategy based on the selection of 10-MDP-based adhesives could be an additional advantage to improve bonding durability of esthetic restorations.

\section{Enzymatic inhibitors}

As mentioned before, one of the foremost impediment for the longevity of adhesive interfaces is degradation of exposed collagen fibrils at the base of the hybrid layer: preservation of their integrity is tough pivotal to improve bonding durability. ${ }^{68}$

Since Pashley et al. ${ }^{37}$ and Armstrong et al. ${ }^{39}$ auspiciously linked such degradation to the action of host derived endogenous matrix metalloproteinases (MMPs) ${ }^{69}$ several approaches to make them inactive, hence slowing down or nullifying the phenomenon, started to be considered. ${ }^{40,68,70,71,72}$ It is well-known that certain substances are promising MMPs inhibitors, but the most studied in adhesive dentistry is chlorhexidine (CHX) ${ }^{37,58,73,74}$ It is, in addition, also capable of inhibiting cysteine cathepsins $(\mathrm{CCs})^{75}$ the other key class of proteolytic enzymes identified in dentin. ${ }^{76}$

$\mathrm{CHX}$ was accordingly shown to partially conserve the integrity of the hybrid layer, ${ }^{77}$, favoring bond durability. CHX can be used as an antiproteolytic "primer" solution directly applied on the dentin surface, or after phosphoric acid etching and rinsing ${ }^{74,78,79,80,81,82}$ or incorporated into the acid etching agent ${ }^{83,84}$ or within the adhesive system composition. ${ }^{74,85,86,87}$

The use of $2 \% \mathrm{CHX}$ solution as an effective and nonspecific protease inhibitor primer, after acid-etching, is attractive from a clinical point of view, since it is already used in other oral health situations as an antimicrobial agent. ${ }^{88}$ Compared to control, aged CHX-treated dentin relates to higher bond strength values ${ }^{73,74,77,78,79,80,89,90,91,92}$ which are interestingly equivalent to each other in most of the immediate evaluations. ${ }^{93}$ Especially when two step etch-and-rinse adhesives are used, reduction of bond strength values for conventionally treated dentin over one to two years is of approximately $50 \%$; when $\mathrm{CHX}$ is applied after acid etching, total reduction is around $20 \%{ }^{72}$ to $84.9 \%{ }^{88}$

Even though the presence of carious-affected dentin, as well as artificially eroded dentin, relates to inferior bond strength values, ${ }^{53,94,95} \mathrm{CHX}$ can preserve adhesive interface stablished by two-step etch-and-rinse adhesives, although not indefinitely. ${ }^{77,96,97,98,99}$ Higher bond strength durability of a two-step self-etch adhesive over 2-year aging in artificial saliva and under simulated intrapulpal pressure was also described 
in the literature when caries-affected dentin was pretreated with $\mathrm{CHX} .{ }^{100}$ Besides, the degradation of the adhesive interface in primary teeth may be counteracted or blocked by the application of $\mathrm{CHX}$ as a therapeutic primer..$^{92,101}$

Avoiding to add another step in the adhesive treatment of dentin, ${ }^{6,88}$ some investigators have studied the beneficial effects of incorporation CHX into the etchant ${ }^{83,84}$ or the adhesive. ${ }^{87,97,102,103,104}$ First strategy was alleged to reduce the effectiveness of $\mathrm{CHX}$ in the inhibition of MMPs and CCs, due to the limited contact time and the little concentration of $\mathrm{CHX}$ at the moment of adhesive application. It should be considered that $\mathrm{CHX}$ is leached from demineralized and mineralized powdered human dentin with water rinsing ${ }^{67}$ However, Loguercio et al. ${ }^{105}$ have identified CHX inside a 5-year aged hybrid layer after application of a CHX-containing etchant. The high substantivity of CHX on dentin may explain inefficiency of the rinsing step in eliminating substantial amounts of it. ${ }^{106}$

CHX incorporated into experimental adhesives, in turn, was proved not to jeopardize immediate bond strength to dentin and to partially reduce the degradation of the resin-dentin bonds after aging. ${ }^{103}$ A reservoir of $\mathrm{CHX}$ for controlled release would be derived from its inclusion into primers and/or adhesives: ${ }^{87}$ addition of relatively low $\mathrm{CHX}$ concentrations to commercial adhesive, chiefly in ethanol-solvated hydrophobic resins, was shown feasible in this sense. ${ }^{85,86,87}$ Controversial results look as if they were related to the concentration of $\mathrm{CHX}$ added to the adhesive formulation and/or to the chemical compositions of the adhesives, $, 93,102,107,108$ which may influence resin water sorption, and hence its solubility, degree of conversion, and mechanical properties. ${ }^{85,109}$ To endorse CHX incorporation into adhesives, Stanislawczuk et al. ${ }^{87}$ advised the conduction of further studies in more clinically relevant conditions. In vitro studies have already attested that CHXcontaining primers of two-step self-etch and simplified etch-and-rinse adhesives are capable of, respectively, inhibiting $\mathrm{MMPs}^{108}$ and reducing nanoleakage, ${ }^{104}$ precluding time-related bond strength loss. ${ }^{102,104}$ An adhesive system containing $0.2 \%$ chlorhexidine (Peak Universal Bond, Ultradent Products Inc, South Jordan, USA) was then just introduced in the market. ${ }^{6}$
As an alternative, Abu Nawareg et al. ${ }^{110}$ successfully used a monomer named CHX-methacrylate (Ivoclar Vivadent, Schaan, Liechtenstein) as a primer to improve hybrid layer long-term stability. In this way, CHX would both bind to demineralized dentin ${ }^{67}$ and copolymerize with adhesive monomers: CHX-methacrylate would be much more than electrostatically bound to the dentin matrix, it would be sealed inside it, maybe for many years. ${ }^{110}$ Then CHX-methacrylate could inhibit matrix proteases probably the same way $\mathrm{CHX}$ digluconate can do..$^{110}$

CHX is a cationic bisbiguanide which inhibits collagenase/gelatinase activity of dentin matrices. ${ }^{74,37,111,112}$ It is believed that it acts by cation chelation, sequestrating calcium and zinc ions that are essential for the activation of the MMPs catalytic domains. ${ }^{111,113,114}$ Even low CHX concentrations (0.002-0.02\%) and short-time applications (15 to 30 seconds) ${ }^{86}$ are effective in minimizing the degradation of adhesive interfaces, but the association between the concentration and the bond strength is not linear. ${ }^{73}$ Lower percent of failure mode in the hybrid layer, especially at the bottom part, found after sixmonth aging when $\mathrm{CHX}$ was applied, was one of the first indicative of its effectiveness as a protease inhibitor in adhesive dentistry. ${ }^{78}$ Later, after $\mathrm{CHX}$ application, improved collagen network formation (better adhesive penetration), reduced collagen degradation, and distinct gold-labeling signals were identified by field emission scanning electron microscopy and immuno-gold staining; a better resin and dentin tube combination was detected in the surface micromorphology of the fractured dentin resin restoration as well. ${ }^{38}$ About long-term effectiveness, it would be explained by the high substantivity of $\mathrm{CHX} \cdot{ }^{106}$ Regardless of its concentration, $\mathrm{CHX}$ has a strong affinity to the dental structure, binding to phosphate groups of mineralized dentin crystallites and to negative carboxyl groups of the collagen matrix (electrostatic forces between $\mathrm{NH}_{3}{ }^{+}$in the $\mathrm{CHX}$ molecule and $\mathrm{COOH}^{-}$or $\mathrm{OH}^{-}$in dentin). ${ }^{106}$ After oversaturating proteases binding sites, if still available (higher concentrations), it can remain bound to collagen fibrils for later release. ${ }^{115}$

Adversely, a limitation of $\mathrm{CHX}$ indication as an enzymatic inhibitor is that its effect seems not to be 
indefinitely long. ${ }^{85}$ Because $\mathrm{CHX}$ molecule is large and water soluble, it may be gradually leached out from the adhesive interface, ${ }^{92}$ especially when in contact with an external environment (through marginal gaps, for instance) ${ }^{105}$ Remaining concentration then becomes no longer appropriate to exert noticeable antiproteolytic effects. ${ }^{92}$

Usage of $\mathrm{CHX}$ on etched dentin before priming plus bonding together, thus when two-step etch-and-rinse adhesives are applied, ${ }^{116}$ is strongly recommended; by the way, demineralization increases $\mathrm{CHX}$ binding to dentin. ${ }^{67,106}$ Its effect on the durability of the bonding when three-step etch and-rinse are used, in turn, appears to be only slightly favorable. Adhesive interfaces determined by using non-simplified etchand-rinse systems are, per se, more stable than that determined by using the simplified counterparts. ${ }^{73}$ Regarding the effectiveness of self-etch adhesives, and even the moment or how $\mathrm{CHX}$ must be applied, are conflicting. ${ }^{74,90,117,118,119}$ Recent systematic reviews show that an aging-associated decline in dentin bond strength of both categories of adhesives can be lessened by CHX application. ${ }^{74,118,119}$ In this sense, a growing predisposition among clinicians in properly applying $0.2-2 \% \mathrm{CHX}$ for $15-60 \mathrm{~s}$ for re-wetting the collagen network on acid-etched dentin $77,79,89,120$ to minimize degradation of resin-dentin bonds, can be currently appreciated. ${ }^{115,119}$ Tough medium-term randomized clinical trials (18-36 months) does not show significant beneficial results from incorporating $\mathrm{CHX}$ to adhesive treatment of dentin. ${ }^{121,122,123}$ Loguercio et al., ${ }^{105}$ incite researchers to evaluate the only one proven clinically and easy to adopt strategy ${ }^{88}$ after long-term follow-ups, when the benefits of $\mathrm{CHX}$ would possibly turn out to be detectable.

Inhibitors of endogenous dentin proteases other than $\mathrm{CHX}$, such as the quaternary ammonium surface-acting benzalkonium chloride (BAC) ${ }^{124,125,126,127}$ the tetracyclines (TCs) and their antimicrobially inactive analogs (minocycline, for now), ${ }^{71,84,128,129,130}$ bisphosphonates (batimastat, galardin, and zoledronate), ${ }^{93,129,131,132}$ green tea polyphenol epigallocatechin-3-gallate (EGCG) ${ }^{40,133,134}$ and the chelating agent ethylenediaminetetraacetic acid (EDTA) ${ }^{135,136,137}$ are being studied as better alternatives associated with dentin hybrid layer preservation.
The same happens to adhesives containing zinc 114,138,139,140,141 or MMP-inhibiting monomers or solvents: polymerizable quaternary ammonium methacrylates (QAMs; e.g. 12-Methacryloyloxydodecylpyridinium bromide / MDPB), ${ }^{66,68,93,125,142,143}$ incorporated into the primer of Clearfil Protect Bond, Kuraray,(6) and dimethyl sulfoxide (DMSO), ${ }^{144,145,146}$ correspondingly. As further efforts are required to ratify related initial encouraging results, for compiled deeper information, one should refer to Perdigão et al. ${ }^{40}$ and Tjäderhane. ${ }^{6}$

Authors claim that, ${ }^{6,41,68}$ although CHX may not be unfailing, it can and should be indicated (often as an optional step before application of etch-and-rinse, or even self-etch, primer / primer plus bonding) until new strategies have been recognized harmless and just as effective in preserving collagen fibrils integrity, thus favoring bonding durability for some time.

\section{Addition of a separate hydrophobic adhesive resin}

Simplified adhesive systems, both two-step etchand-rinse and one step self-etch adhesives, are composed of high concentrations of hydrophilic resin monomers and a higher amount of water than their more complex counterparts, namely three-step etch-and-rinse and two-step self-etch adhesives. This composition is necessary as water is required to dissociate the weak acidic methacrylate monomers into ionized forms for permeation into dentin. ${ }^{16}$ However, the excess water may prevent the optimal polymerization of the adhesive monomers, thereby reducing the mechanical properties of the adhesive layer and the resulting resin-dentin bond strength. Additionally, due to their high hydrophilicity, such simplified adhesives remain permeable upon polymerization, permitting movement of water from both the host tooth as well as from the outer oral cavity across the interface. ${ }^{147}$

To counteract this limitation of simplified adhesives, it has been proposed that the application of an additional layer of hydrophobic fluid resin should be incorporated to their bonding protocol. ${ }^{24,148,149,150,151,152}$ This strategy proved to be effective in minimizing nanoleakage and improving the polymerization of simplified adhesives ${ }^{150}$ as well as their immediate ${ }^{40,146,150}$ and long-term ${ }^{146}$ bond strength. It could also improve the sealing ability of 
two-step etch-and-rinse adhesives by reducing fluid conductance across the adhesive interface. ${ }^{151}$

All things considered, an extra coating of hydrophobic resin should be applied over dentin treated with both simplified adhesive systems, etch-and-rinse or self-etch. Advantages of this technique can be the improvement of marginal sealing, bond strength and degree of conversion, together with a reduced post-operative hypersensitivity. ${ }^{6}$

\section{Selective enamel acid-etching}

Contrary to the possible shortcomings of etching dentin with phosphoric acid, its selective application on enamel seems to have been recognized as a key step toward the clinical success of self-etch protocol, ${ }^{153}$ especially when mild and ultra-mild adhesives are considered. ${ }^{154,15,156}$ The $\mathrm{pH}$ of self-etch and self-adhesive materials directly relates to their reduced potential, as compared to that of phosphoric acid, ${ }^{157,158}$ to etch the highly-mineralized enamel. ${ }^{25,155,156,157,159,160,161,162,163,164}$ Hence, increasing its surface area and creating deep etch-pits remains important for the achievement of an effective and durable bond to enamel. ${ }^{4,165,166,167,168}$ According to the buffering capacity that such substrate offers to the action of self-etch systems in general, it can be expected that they do have a lower demineralizing effect on the hydroxyapatite-rich enamel, which ultimately compromise their bonding effectiveness. ${ }^{169,170}$

Several in vitro studies proved that higher bond strength of self-etch systems to enamel is achieved with the selective phosphoric acid etching technique. ${ }^{161,171,172,173,174}$ The same proved true, in recent times, for universal adhesives. . $^{17,168,170,175,176}$ Performing selective enamel etching implies in less marginal discoloration and better marginal adaptation. ${ }^{24,177,178,179,180,181}$ Likewise, an interesting meta-analysis communicated by Peumans et al. ${ }^{28}$ showed that selective etching reduces the clinical annual failure rates of mild self-etch systems, notwithstanding this was not true when clinical trials were evaluated separately. Also, retention rates of restorations of NCCLs might be improved by selective application of phosphoric acid on enamel and further employment of self-etch adhesives. ${ }^{175}$

It is suggested, therefore, that prior acid etching of enamel with phosphoric acid should be a routine procedure when using any self-etch protocol, to achieve higher retention of the resinous material, 5,172,173 especially in more critical situations due to the structure of the substrate: unground/aprismatic enamel; or due to the lack of inherent form of retention of certain cavity profiles a sin the case of Class IV cavities, fractures in anterior teeth, and luting laminate veneers, for instance. ${ }^{9114,153,160,182}$ Selective acid-etching is increasingly more suitable the greater the amount of remaining enamel. ${ }^{182}$

\section{Cross-linkers}

Type I collagen represents the major component of the organic matrix of hard tissues and its stiffness depends on the formation of endogenous and exogenous cross-links. ${ }^{183}$ Collagen is a heterotrimeric molecule composed of two $\alpha 1$ and one $\alpha 2$ chains that are comprised of three domains: NH2-terminal (N-telopeptide), the central triple helix and the $\mathrm{COOH}$-terminal non-triple helical (C-telopeptide) domain. ${ }^{184}$

Endogenous collagen cross-links are mediated by both non-enzymatic and enzymatic reactions. Non-enzymatic collagen cross-links are mediated by oxidation and glycation processes, ${ }^{185}$ while enzymatic reactions happen between the telopeptide and adjacent triple helical chains, ${ }^{186}$ which is mediated by chemical reactions through lysyl oxidase covalent bonding. ${ }^{187,188}$ This results in the formation of inter and intra-molecular and inter-microfibrillar cross-links. ${ }^{187,188,199,190,191}$ Such enzymatic reactions are the basis of tissue stability, viscoelasticity and strength of collagen fibrils. ${ }^{184,192}$ In particular, intra-molecular cross-links provide primarily biostability to the collagen molecule, while intermolecular and inter-microfibrillar cross-links enhance mechanical properties, in addition to fibril biostability. ${ }^{193}$

Exogenous cross-linking agents have been proposed to mimic physiological cross-links. They increase the intrinsic properties of the collagen against collagenases degradation through inducing additional formation of inter and intra-molecular cross-links. ${ }^{194,195}$ Exogenous cross-links also improve biomechanical and biostability properties of collagen fibrils ${ }^{196}$ and are mediated by non-enzymatic reaction sources, such as chemical agents (i.e. glutaraldehyde, carbodiimide hydrochloride and natural resources) and physical methods. ${ }^{196}$ 
Physical methods are mediated by photo-oxidative reaction, usually by light exposure, such as ultraviolet radiation (UVA). ${ }^{197}$ Riboflavin is the most common cross-link of this class that can be induced by UVA. However, the use of UVA in clinical practice is unfeasible.

Among the great variability of synthetic chemical agents, the most widely known is Glutaraldehyde (GA). ${ }^{68,196}$ GA can induce cross-links in collagen, consequently enhancing its mechanical properties, such as hardness, and maintaining its mechanical stability. GA may also prevent matrix degradation by crosslinking the binding and/or active sites of endogenous dentin MMPs, therefore blocking the access of such enzymes. ${ }^{198}$ However, its high cytotoxicity makes its clinical use inappropriate. ${ }^{196}$

Carbodiimide hydrochloride (EDC) has also been proposed as an effective collagen cross-linker as it has been shown to improve the durability and structural integrity of the adhesive interface, thus preserving its bond strength over time, and this through the formation of inter- and intra-molecular cross-links. ${ }^{199,200,201,202}$ Moreover, EDC is one of the least cytotoxic and most stable cross linkers. ${ }^{58}$ EDC also seems to be capable of inactivating dentinal gelatinases. ${ }^{200,201,202}$ It should be considered, however, that it is currently designed to be used just after acid-etching, in etch-and-rinse adhesives. ${ }^{58}$

Genipin is a natural cross-linking agent that can react with the amino groups of lysine, hydroxylysine or arginine to form intra or inter-molecular cross-links within collagen molecule or between adjacent collagen molecules. ${ }^{195,203}$ However, the rates of induced exogenous cross-links are slow, which represents a limiting factor as far as treatment of dentin is taken into account. ${ }^{204}$

Proantocianidin (PA) is a polyphenolic compound that can be extracted from several fruits, nuts, vegetables and barks. ${ }^{195,205}$ Their interaction with collagen type I depends on the type of PA, chemical structure, stereochemistry pattern and concentration of these natural extracts. ${ }^{206,207} \mathrm{PA}$ is a natural cross-linking agent that has been widely studied in recent years due to their ability to biomodify the dentin matrix $^{184}$ and enhance its mechanical properties and resistance against biodegradation, finally favoring the resin/dentin bond strengths. ${ }^{199,204} \mathrm{PA}$ can interact with collagen tissue and induce non-enzymatic collagen cross-linking ${ }^{193}$ increasing collagen stiffness and dentin bond strength by keeping the bonding stable over time. ${ }^{207}$

Even though crosslinkers proved to be efficient in enhancing mechanical properties of dentin, and impairing degradation of the dentin-resin interface, researchers did not reach the exact point to recommend its clinical use. More studies are necessary to turn this promising strategy into a clinically effective protocol.

\section{Ethanol - wet Bonding}

The development of a promising bonding procedure on dentin is still challenging due to its humid and porous intrinsic biological features. The formation of a stable hybrid layer depends on an efficient penetration of resin monomers for a tight encapsulation of the exposed collagen matrix. ${ }^{208}$ However, this ideal hybrid layer is difficult to obtain, being therefore prone to hydrolytic degradation of collagen fibrils and adhesive polymers. ${ }^{40,46,209}$

The "ethanol wet bonding" technique consists of gradually replacing water from interfibrillar and intrafibrillar spaces by ethanol, starting with the application of lower concentrations of ethanol solutions and slowly progressing to higher concentrations up to a complete dehydration of the exposed collagen network. ${ }^{13,210,211,212}$. Ethanol has a higher vapor pressure than water, enhancing its evaporation and creating wider interfibrilar spaces for impregnation of hydrophobic monomers to form a more stable hybrid layer. ${ }^{213,214,215}$

Basically, ethanol dehydrates the demineralized collagen matrix and coaxes hydrophobic monomers into it. ${ }^{216}$ This technique also prevents phase separation of hydrophobic resin monomers in the presence of water, ${ }^{217,218,219}$ since the latter is completely replaced by ethanol prior to the application of the ethanolsoluble monomers. ${ }^{220,221}$ Additionally, the elimination of residual water seems to contribute to decrease or even eliminate hydrolytic enzymatic degradation of collagen fibrils, ${ }^{212,222}$ thereby increasing bond durability and stability. ${ }^{213}$

However, this technique is very sensitive, time consuming and requires the application of many 
steps to achieve the desired dehydration, which becomes inappropriate. More studies are necessary to improve this protocol for clinical use.

\section{Conclusion}

Our main objective towards the formation of a strong and durable bond to tooth structure is to create on dentin a hybrid layer which is completely free of voids so that the collagen network becomes fully protected against hydrolytic and enzymatic degradation. However, based on the current state of the art, this task seems impossible to be fully achieved. Basically, the adhesive interface as we know today is the antithesis of a completely successful bonding, especially from a nanoscale and molecular standpoint. On the other hand, we do believe that there are materials and strategies that can certainly help to prevent degradation within the adhesive interface. It is fundamental that professionals are aware of these strategies to counteract degradation as much as possible. None of them are efficient to completely solve the problem, but they certainly represent reasonable alternatives to increase the lifetime of adhesive restorations. In a nutshell, we could mention:

a. Preserve as much as possible enamel on cavity margins;

\section{References}

1. Alexander G, Hopcraft MS, Tyas MJ, Wong R. Dentists' restorative decision-making and implications for an "amalgamless" profession. Part 3: Dentists' attitudes. Aust Dent J. 2016;61(4):502-13. https://doi.org/10.1111/adj.12419

2. Lynch $\mathrm{CD}$, Wilson NH. Managing the phase-down of amalgam: Part I. Educational and training issues. Br Dent J. 2013;215(3):109-13. https://doi.org/10.1038/sj.bdj.2013.737

3. Nakabayashi N, Siami Y. Bonding to intact dentin. J Dent Res. 1996;75(9):1706-15. https://doi.org/10.1177/00220345960750091401

4. Pashley DH, Tay FR, Breschi L, Tiäderhane L, Carvalho RM, Carrilho $M$ et al. State of the art etch-and-rinse adhesives. Dent Mater. 2011;27(1):1-16. https://doi.org/10.1016/i.dental.2010.10.016 b. Remove all infected dentin;

c. Remove caries-affected dentin from surrounding walls, maintaining it at pulpal and axial walls;

d. Maintain the correct humidity of dentin, according to the type of bonding agent used;

e. Use selective acid etching for self-etch agents when cavities margins are on enamel;

f. Clean cavities with anionic detergent before proceeding with the restorative protocol;

g. Make sure your curing unit is effective with the right wavelength per photo initiators of the bonding systems. Thus, follow manufacturer's instructions;

h. When opting for self-etching strategies, give preference to those promoting chemical adhesion to the dental substrate, especially those based on 10-MDP.

i. An extra coating of hydrophobic resin should be applied over dentin treated with any of the currently available simplified bonding agents.

\section{Acknowledgements}

Authors are indebted to Professor Giuseppe Alexandre Romito, editor-in-chief of Brazilian Oral Research, for kindly inviting corresponding author to write down this literature review. They declare no potential conflicts of interest with respect to the authorship and/or publication of this article.

5. Van Meerbeek B, Yoshihara K, Yoshida Y, Mine A, De Munck J, Van Landuyt KL. State of the art of self-etch adhesives. Dent Mater. 2011;27(1):17-28. https://doi.org/10.1016/j.dental.2010.10.023

6. Tiäderhane L. Dentin bonding: can we make it last? Oper Dent. 2015;40(1):4-18. https://doi.org/10.2341/14-095-BL

7. Yoshiyama M, Carvalho R, Sano H, Horner J, Brewer PD, Pashley DH. Interfacial morphology and strength of bonds made to superficial versus deep dentin. Am J Dent. 1995;8(6):297-302.

8. Van Meerbeek B, Peumans $M$, Poitevin A, Mine A, Van Ende A, Neves A et al. Relationship between bond-strength tests and clinical outcomes. Dent Mater. 2010;26(2):e100-21. https://doi.org/10.1016/j.dental.2009.11.148 
9. De Munck J, Van Landuyt K, Peumans M, Poitevin A, Lambrechts P, Braem M et al. A critical review of the durability of adhesion to tooth tissue: methods and results. J Dent Res. 2005;84(2):118-32. https://doi.org/10.1177/154405910508400204

10. Reis A, Zander-Grande C, Kossatz S, Stanislawczuk R, Manso A, Carvalho RM et al. Effect of mode of application on the microtensile bond strength of a self-etch and etch-and-rinse adhesive system. Oper Dent. 2010;35(4):428-35. https://doi.org/10.2341/09-319-L

11. Kanca J 3rd. Improving bond strength through acid etching of dentin and bonding to wet dentin surfaces. J Am Dent Assoc. 1992;123(9):35-43. https://doi.org/10.14219/jada.archive.1992.0248

12. Tay FR, Gwinnett AJ, Pang KM, Wei SH. Structural evidence of a sealed tissue interface with a total-etch wet-bonding technique in vivo. J Dent Res. 1994;73(3):629-36. https://doi.org/10.1177/00220345940730030801

13. Pashley DH, Tay FR, Carvalho RM, Rueggeberg FA, Agee KA, Carrilho $\mathrm{M}$ et al. From dry bonding to water-wet bonding to ethanol-wet bonding: a review of the interactions between dentin matrix and solvated resins using a macromodel of the hybrid layer. Am J Dent. 2007;20(1):7-20.

14. Van Meerbeek B, De Munck J, Yoshida Y, Inoue S, Vargas M, $V_{i j a y} P$ et al. Buonocore memorial lecture. Adhesion to enamel and dentin: current status and future challenges. Oper Dent. 2003;28(3):215-35.

15. Moszner N, Salz U, Zimmermann J. Chemical aspects of self-etching enamel-dentin adhesives: a systematic review. Dent Mater. 2005;21(10):895-910. https://doi.org/10.1016/i.dental.2005.05.001

16. Van Landuyt KL, Snauwaert J, De Munck J, Peumans M, Yoshida Y, Poitevin A et al. Systematic review of the chemical composition of contemporary dental adhesives. Biomaterials. 2007;28(26):3757-85. https://doi.org/10.1016/j.biomaterials.2007.04.044

17. Rosa WL, Piva E, Silva AF. Bond strength of universal adhesives: a systematic review and meta-analysis. J Dent. 2015;43(7):765-76. https://doi.org/10.1016/i.jdent.2015.04.003

18. Yoshida Y, Nagakane K, Fukuda R, Nakayama Y, Okazaki M, Shintani $\mathrm{H}$ et al. Comparative study on adhesive performance of functional monomers. J Dent Res. 2004;83(6):454-8. https://doi.org/10.1177/154405910408300604

19. Van Landuyt KL, Yoshida Y, Hirata I, Snauwaert J, De Munck J, Okazaki M et al. Influence of the chemical structure of functional monomers on their adhesive performance. J Dent Res. 2008;87(8):757-61. https://doi.org/10.1177/154405910808700804

20. Yoshida Y, Van Meerbeek B, Nakayama Y, Snauwaert J, Hellemans L, Lambrechts $P$ et al. Evidence of chemical bonding at biomaterial-hard tissue interfaces. J Dent Res. 2000;79(2):709-14. https://doi.org/10.1177/00220345000790020301
21. Hanabusa M, Mine A, Kuboki T, Momoi Y, Van Ende A, Van Meerbeek B et al. Bonding effectiveness of a new "multi-mode" adhesive to enamel and dentine. J Dent. 2012;40(6):475-84. https://doi.org/10.1016/i.jdent.2012.02.012

22. Marchesi G, Frassetto A, Mazzoni A, Apolonio F, Diolosà $M$, Cadenaro $M$ et al. Adhesive performance of a multi-mode adhesive system: 1-year in vitro study. J Dent. 2014;42(5):603-12. https://doi.org/10.1016/i.jdent.2013.12.008

23. Perdigão J, Kose C, Mena-Serrano AP, De Paula EA, Tay LY, Reis A et al. A new universal simplified adhesive: 18-month clinical evaluation. Oper Dent. 2014;39(2):113-27. https://doi.org/10.2341/13-045-C

24. Perdigão J, Muñoz MA, Sezinando A, Luque-Martinez IV, Staichak R, Reis $A$ et al. Immediate adhesive properties to dentin and enamel of a universal adhesive associated with a hydrophobic resin coat. Oper Dent. 2014;39(5):489-99. https://doi.org/10.2341/13-203-LR

25. Torii Y, Itou K, Nishitani Y, Ishikawa K, Suzuki K. Effect of phosphoric acid etching prior to self-etching primer application on adhesion of resin composite to enamel and dentin. Am J Dent. 2002;15(5):305-8. https://doi.org/10.1016/i.dental.2005.05.010

26. Van Landuyt KL, Peumans M, De Munck J, Lambrechts $P$, Van Meerbeek B. Extension of a one-step self-etch adhesive into a multi-step adhesive. Dent Mater. 2006;22(6):533-44.

27. Goracci C, Rengo C, Eusepi L, Juloski J, Vichi A, Ferrari M. Influence of selective enamel etching on the bonding effectiveness of a new "all-in-one" adhesive. Am J Dent. 2013;26(2):99-104.

28. Peumans M, De Munck J, Mine A, Van Meerbeek B. Clinical effectiveness of contemporary adhesives for the restoration of non-carious cervical lesions: a systematic review. Dent Mater. 2014;30(10):1089-103. https://doi.org/10.1016/j.dental.2014.07.007

29. Mount GJ, Hume WR, editors. Preservation and restoration of tooth structure. 2nd ed. Brisbane: Knowledge; 2005.

30. Inove S, Van Meerbeek B, Abe Y, Yoshida Y, Lambrechts P, Vanherle $G$ et al. Effect of remaining dentin thickness and the use of conditioner on micro-tensile bond strength of a glass-ionomer adhesive. Dent Mater. 2001;17(5):445-.55. https://doi.org/10.1016/S0109-5641(01)00003-3

31. Van Meerbeek B, Vargas S, Inoue S, Yoshida Y, Peumans M, Lambrechts $\mathrm{P}$ et al. Adhesives and cements to promote preservation dentistry. Oper Dent. 2001;26:S119-44.

32. Mickenautsch S, Yengopal V. Failure rate of high-viscosity GIC based ART compared with that of conventional amalgam restorations: evidence from an update of a systematic review. SADJ. 2012;67(7):329-31.

33. Loguercio $A D$, Reis $A$, Barbosa AN, Roulet JF. Five-year double-blind randomized clinical evaluation of a resin-modified glass ionomer and a polyacid-modified resin in noncarious cervical lesions. J Adhes Dent. 2003;5(4):323-32. 
34. Gurgan S, Kutuk ZB, Ergin E, Oztas SS, Cakir FY. Clinical performance of a glass ionomer restorative system: a 6-year evaluation. Clin Oral Investig. 2016. https://doi.org/10.1007/s00784-016-2028-4

35. Türkün LS, Kanik Ö. A prospective six-year clinical study evaluating reinforced glass ionomer cements with resin coating on posterior teeth: quo vadis? Oper Dent. 2016;41(6):587-98. https://doi.org/10.2341/15-331-C

36. Sano H. Microtensile testing, nanoleakage, and biodegradation of resin-dentin bonds. J Dent Res. 2006 85(1):11-4. https://doi.org/10.1177/154405910608500102

37. Pashley DH, Tay FR, Yiu C, Hashimoto M, Breschi L, Carvalho RM et al. Collagen degradation by host-derived enzymes during aging. J Dent Res. 2004;83(3):216-21. https://doi.org/10.1177/154405910408300306

38. Li H, Li T, Li X, Zhang Z, Li P, Li Z. Morphological effects of MMPs inhibitors on the dentin bonding. Int J Clin Exp Med. 2015;8(7):10793-803.

39. Armstrong SR, Vargas MA, Chung I, Pashley DH, Campbell JA, Laffoon JE et al. Resin-dentin interfacial ultrastructure and microtensile dentin bond strength after five-year water storage. Oper Dent. 2004;29(6):705-12.

40. Perdigão J, Reis A, Loguercio AD. Dentin adhesion and MMPs: a comprehensive review. J Esthet Restor Dent. 2013;25(4):219-41. https://doi.org/10.1111/jerd.12016

41. Breschi L, Mazzoni A, Ruggeri A, Cadenaro M, Di Lenarda R, De Stefano Dorigo E. Dental adhesion review: aging and stability of the bonded interface. Dent Mater. 2008;24(1):90-101. https://doi.org/10.1016/i.dental.2007.02.009

42. Ferracane JL. Hygroscopic and hydrolytic effects in dental polymer networks. Dent Mater. 2006;22(3):211-22. https://doi.org/10.1016/i.dental.2005.05.005

43. Reis A, Grande RH, Oliveira GM, Lopes GC, Loguercio AD. A 2-year evaluation of moisture on microtensile bond strength and nanoleakage. Dent Mater. 2007;23(7):862-70. https://doi.org/10.1016/i.dental.2006.05.005

44. Grenier D. Reduction of proteolytic degradation by chlorhexidine. J Dent Res. 1993;72(3):630-3. https://doi.org/10.1177/00220345930720031301

45. Tay FR, Pashley DH, Suh B, Carvalho R, Miller M. Single-step, self-etch adhesives behave as permeable membranes after polymerization. Part I. Bond strength and morphologic evidence. Am J Dent. 2004;17(4):271-8.

46. Ito S, Hashimoto M, Wadgaonkar B, Svizero N, Carvalho RM, Yiu $C$ et al. Effects of resin hydrophilicity on water sorption and changes in modulus of elasticity. Biomaterials. 2005;26(33):6449-59. https://doi.org/10.1016/j.biomaterials.2005.04.052

47. Tiäderhane L, Lariava $H$, Sorsa $T$, Uitto VJ, Larmas M, Salo T. The activation and function of host matrix metalloproteinases in dentin matrix breakdown in caries lesions. J Dent Res. 1998;77(8):1622-9. https://doi.org/10.1177/00220345980770081001
48. Stanislawczuk R, Costa JA, Polli LG, Reis A, Loguercio AD. Effect of tetracycline on the bond performance of etch-and-rinse adhesives to dentin. Braz Oral Res. 2011;25(5):459-65. https://doi.org/10.1590/S1806-83242011000500014

49. Balooch M, Habelitz S, Kinney JH, Marshall SJ, Marshall GW. Mechanical properties of mineralized collagen fibrils as influenced by demineralization. J Struct Biol. 2008;162(3):404-10. https://doi.org/10.1016/i.jsb.2008.02.010

50. Bertassoni LE, Orgel JP, Antipova O, Swain MV. The dentin organic matrix: limitations of restorative dentistry hidden on the nanometer scale. Acta Biomater 2012;8(7):2419-33. https://doi.org/10.1016/i.actbio.2012.02.022

51. Bella J, Brodsky B, Berman HM. Hydration structure of a collagen peptide. Structure. 1995;3(9):893-906. https://doi.org/10.1016/S0969-2126(01)00224-6

52. Erhardt MC, Rodrigues JA, Valentino TA, Ritter AV, Pimenta LA. In vitro microTBS of one-bottle adhesive systems: sound versus artificially-created caries-affected dentin. J Biomed Mater Res B Appl Biomater. 2008;6(1):181-7. https://doi.org/10.1002/ibm.b.31004

53. Yoshiyama M, Tay FR, Doi J, Nishitani Y, Yamada T, Itou $\mathrm{K}$ et al. Bonding of self-etch and total-etch adhesives to carious dentin. J Dent Res. 2002;81(8):556-60. https://doi.org/10.1177/154405910208100811

54. Wang Y, Spencer P, Walker MP. Chemical profile of adhesive/caries-affected dentin interfaces using Raman microspectroscopy J Biomed Mater Res A 2007;81 (2):279-86. https://doi.org/10.1002/jbm.a.3098

55. Sano H, Ciucchi B, Matthews WG, Pashley DH. Tensile properties of mineralized and demineralized human and bovine dentin J Dent Res. 1994;73(6):1205-11.

56. Neves AA, Coutinho E, Cardoso MV, Lambrechts P, Van Meerbeek B. Current concepts and techniques for caries excavation and adhesion to residual dentin. J Adhes Dent. 2011;13(1):7-22. https://doi.org/10.3290/i.jad.a18443

57. Aykut-Yetkiner A, Simşek D, Eronat C, Ciftçioğlu M. Comparison of the remineralisation effect of a glass ionomer cement versus a resin composite on dentin of primary teeth. Eur J Paediatr Dent. 2014;15(2):119-21.

58. Tiäderhane L, Nascimento FD, Breschi $L$, Mazzoni A, Tersariol IL, Geraldeli S et al. Strategies to prevent hydrolytic degradation of the hybrid layer-A review. Dent Mater. 2013;29(10):999-1011. https://doi.org/10.1016/j.dental.2013.07.016

59. Feitosa VP, Ogliari FA, Van Meerbeek B, Watson TF, Yoshihara K, Ogliari AO et al. Can the hydrophilicity of functional monomers affect chemical interaction? J Dent Res. 2014;93(2):201-6. https://doi.org/10.1177/0022034513514587

60. Inoue S, Koshiro K, Yoshida Y, De Munck J, Nagakane K, Suzuki $\mathrm{K}$ et al. Hydrolytic stability of self-etch adhesives bonded to dentin. J Dent Res. 2005;84(12):1160-4. https://doi.org/10.1177/154405910508401213 
61. Fujita K, Nishiyama N. 13C NMR analysis of the etching efficacy of acidic monomers in self-etching primers. J Dent. 2006;34(2):123-33. https://doi.org/10.1016/i.jdent.2005.04.005

62. Coutinho E, Yoshida Y, Inoue S, Fukuda R, Snauwaert J, Nakayama $Y$ et al. Gel phase formation at resin-modified glass-ionomer/tooth interfaces. J Dent Res. 2007;86(7):656-61. https://doi.org/10.1177/154405910708600714

63. Yoshida Y, Van Meerbeek B, Nakayama Y, Yoshioka M, Snauwaert J, Abe $Y$ et al. Adhesion to and decalcification of hydroxyapatite by carboxylic acids. J Dent Res. 2001;80(6):1565-9. https://doi.org/10.1177/00220345010800061701

64. Yoshihara K, Yoshida Y, Nagaoka N, Fukegawa D, Hayakawa S, Mine A et al. Nano-controlled molecular interaction at adhesive interfaces for hard tissue reconstruction. Acta Biomater. 2010;6(9):3573-82. https://doi.org/10.1016/j.actbio.2010.03.024

65. Fukegawa D, Hayakawa S, Yoshida Y, Suzuki K, Osaka A, Van Meerbeek B. Chemical interaction of phosphoric acid ester with hydroxyapatite. J Dent Res. 2006;85(10):941-4. https://doi.org/10.1177/154405910608501014

66. Van Landuyt KL, De Munck J, Mine A, Cardoso MV, Peumans M, Van Meerbeek B. Filler debonding \& subhybrid-layer failures in self-etch adhesives. J Dent Res. 2010;89(10):1045-50. https://doi.org/10.1177/0022034510375285

67. Kim J, Uchiyama T, Carrilho M, Agee KA, Mazzoni A, Breschi $L$ et al. Chlorhexidine binding to mineralized versus demineralized dentin powder. Dent Mater. 2010;26(8):771-8. https://doi.org/10.1016/i.dental.2010.04.001

68. Tiäderhane L, Nascimento FD, Breschi L, Mazzoni A, Tersariol IL, Geraldeli S et al. Optimizing dentin bond durability: control of collagen degradation by matrix metalloproteinases and cysteine cathepsins. Dent Mater. 2013;29(1):116-35. https://doi.org/10.1016/i.dental.2012.08.004

69. Mazzoni A, Nascimento FD, Carrilho M, Tersariol I, Papa V, Tiäderhane $L$ et al. MMP activity in the hybrid layer detected with in situ zymography. J Dent Res. 2012;91(5):467-72. https://doi.org/10.1177/0022034512439210

70. Liu Y, Tiäderhane L, Breschi L, Mazzoni A, Li N, Mao J et al. Limitations in bonding to dentin and experimental strategies to prevent bond degradation. J Dent Res. 2011;90(8):953-68. https://doi.org/10.1177/0022034510391799

71. Tiäderhane L, Sulkala M, Sorsa T, Teronen O, Larmas M, Salo T. The effect of MMP inhibitor metastat on fissure caries progression in rats. Ann N Y Acad Sci. 1999; 8781 INHIBITION OF:686-8. https://doi.org/10.1111/j.1749-6632.1999.tb07762.x

72. Reis A, Carrilho M, Breschi L, Loguercio AD. Overview of clinical alternatives to minimize the degradation of the resin-dentin bonds. Oper Dent. 2013;38(4):E1-25. https://doi.org/10.2341/12-258-LIT
73. Collares FM, Rodrigues SB, Leitune VC, Celeste RK, Araújo FB, Samuel SM. Chlorhexidine application in adhesive procedures: a meta-regression analysis. J Adhes Dent. 2013;15(1):11-8. https://doi.org/10.3290/i.jad.a28732.

74. Montagner AF, Sarkis-Onofre R, Pereira-Cenci T, Cenci MS. MMP Inhibitors on Dentin Stability: A Systematic Review and Meta-analysis. J Dent Res. 2014;93(8):733-43. https://doi.org/10.1177/0022034514538046

75. Scaffa PM, Vidal CM, Barros N, Gesteira TF, Carmona AK, Breschi $L$ et al. Chlorhexidine inhibits the activity of dental cysteine cathepsins. J Dent Res. 2012;91(4):420-5. https://doi.org/10.1177/0022034511435329

76. Tersariol IL, Geraldeli S, Minciotti CL, Nascimento FD, Pääkkönen V, Martins MT et al. Cysteine cathepsins in human dentin-pulp complex. J Endod. 2010;36(3):475-81. https://doi.org/10.1016/i.joen.2009.12.034

77. Hebling J, Pashley DH, Tiäderhane L, Tay FR. Chlorhexidine arrests subclinical degradation of dentin hybrid layers in vivo. J Dent Res. 2005;84(8):741-6. https://doi.org/10.1177/154405910508400811

78. Carrilho MR, Carvalho RM, Goes MF, Hipólito V, Geraldeli S, Tay FR et al. Chlorhexidine preserves dentin bond in vitro. J Dent Res. 2007;86(1):90-4. https://doi.org/10.1177/154405910708600115

79. Carrilho MR, Geraldeli S, Tay F, Goes MF, Carvalho RM, Tiäderhane $L$ et al. In vivo preservation of the hybrid layer by chlorhexidine. J Dent Res. 2007b;86(6):529-33. https://doi.org/10.1177/154405910708600608

80. Breschi L, Cammelli F, Visintini E, Mazzoni A, Vita F, Carrilho $\mathrm{M}$ et al. Influence of chlorhexidine concentration on the durability of etch-and-rinse dentin bonds: a 12-month in vitro study. J Adhes Dent. 2009;11(3):191-8.

81. Breschi L, Mazzoni A, Nato F, Carrilho M, Visintini E, Tiäderhane $L$ et al. Chlorhexidine stabilizes the adhesive interface: a 2-year in vitro study. Dent Mater. 2010;26(4):320-5. https://doi.org/10.1016/j.dental.2009.11.153

82. Loguercio AD, Stanislawczuk R, Polli LG, Costa JA, Michel MD, Reis A. Influence of chlorhexidine digluconate concentration and application time on resin-dentin bond strength durability. Eur J Oral Sci. 2009;117(5):587-96. https://doi.org/10.1111/j.1600-0722.2009.00663.x

83. Stanislawczuk R, Amaral RC, Zander-Grande C, Gagler D, Reis A, Loguercio AD. Chlorhexidine-containing acid conditioner preserves the longevity of resin-dentin bonds. Oper Dent. 2009;34(4):481-90. https://doi.org/10.2341/08-016-L

84. Stanislawczuk R, Reis A, Loguercio AD. A 2-year in vitro evaluation of a chlorhexidine-containing acid on the durability of resin-dentin interfaces. J Dent. 2011;39(1):40-7. https://doi.org/10.1016/j.jdent.2010.10.001

85. Hiraishi N, Yiu CK, King NM, Tay FR, Pashley DH. Chlorhexidine release and water sorption characteristics of chlorhexidine-incorporated hydrophobic/hydrophilic resins. Dent Mater. 2008;24(10):1391-9. https://doi.org/10.1016/j.dental.2008.03.011 
86. Nishitani Y, Hosaka K, Hoshika T, Yoshiyama M, Pashley DH. Effects of chlorhexidine in self-etching adhesive: 24 hours results. Dent Mater J. 2013;32(3):420-4. https://doi.org/10.4012/dmi.2012-199

87. Stanislawczuk R, Reis A, Malaquias P, Pereira F, Farago PV, Meier MM et al. Mechanical properties and modeling of drug release from chlorhexidine-containing etch-and-rinse adhesives. Dent Mater. 2014b;30(4):392-9. https://doi.org/10.1016/j.dental.2014.01.007

88. Dionysopoulos D. Effect of digluconate chlorhexidine on bond strength between dental adhesive systems and dentin: a systematic review. J Conserv Dent. 2016;19(1):11-6. https://doi.org/10.4103/0972-0707.173185

89. Brackett MG, Tay FR, Brackett WW, Dib A, Dipp FA, Mai $S$ et al. In vivo chlorhexidine stabilization of hybrid layers of an acetone-based dentin adhesive. Oper Dent. 2009;34(4):379-83. https://doi.org/10.2341/08-103

90. Campos EA, Correr GM, Leonardi DP, Pizzatto E, Morais EC. Influence of chlorhexidine concentration on microtensile bond strength of contemporary adhesive systems. Braz Oral Res. 2009;23(3):340-5. https://doi.org/10.1590/S1806-83242009000300019

91. Campos EA, Correr GM, Leonardi DP, BaratoFilho F, Gonzaga CC, Zielak JC. Chlorhexidine diminishes the loss of bond strength over time under simulated pulpal pressure and thermomechanical stressing. J Dent. 2009b;37(2):108-14. https://doi.org/10.1016/j.jdent.2008.10.003

92. Ricci HA, Sanabe ME, de Souza Costa CA, Pashley DH, Hebling J. Chlorhexidine increases the longevity of in vivo resin-dentin bonds. Eur J Oral Sci. 2010;118(4):411-6. https://doi.org/10.1111/j.1600-0722.2010.00754.x

93. De Munck J, Mine A, Van den Steen PE, Van Landuyt KL, Poitevin A, Opdenakker $G$ et al. Enzymatic degradation of adhesive-dentin interfaces produced by mild self-etch adhesives. Eur J Oral Sci. 2010;118(5):494-501. https://doi.org/10.1111/i.1600-0722.2010.00758.x

94. Nakajima M, Sano H, Burrow MF, Tagami J, Yoshiyama M, Ebisu $S$ et al. Tensile bond strength and SEM evaluation of caries-affected dentin using dentin adhesives. J Dent Res. 1995;74(10):1679-88 https://doi.org/10.1177/00220345950740100901

95. Doi J, Itota T, Torii Y, Nakabo S, Yoshiyama M. Micro-tensile bond strength of self-etching primer adhesive systems to human coronal carious dentin. J Oral Rehabil. 2004;31(10):1023-8. https://doi.org/10.1111/i.1365-2842.2004.01339.x

96. Komori PC, Pashley DH, Tjäderhane L, Breschi L, Mazzoni A, Goes MF et al. Effect of $2 \%$ chlorhexidine digluconate on the bond strength to normal versus caries-affected dentin. Oper Dent. 2009;34(2):157-65. https://doi.org/10.2341/08-55

97. Ekambaram M, Yiu CK, Matinlinna JP, King NM, Tay FR. Adjunctive application of chlorhexidine and ethanol-wet bonding on durability of bonds to sound and caries-affected dentine. J Dent. 2014;42(6):709-19. https://doi.org/10.1016/i.jdent.2014.04.001

98. Francisconi-dos-Rios LF, Calabria MP, Casas-Apayco LC, Honório HM, Carrilho MR, Pereira JC et al. Chlorhexidine does not improve but preserves bond strength to eroded dentin. Am J Dent. 2015;28(1):28-32.

99. Francisconi-dos-Rios LF, Casas-Apayco LC, Calabria MP, Francisconi PA, Borges AF, Wang L. Role of chlorhexidine in bond strength to artificially eroded dentin over time. J Adhes Dent. 2015;17(2):133-9. https://doi.org/10.3290/i.jad.a34059.

100. Mobarak EH. Effect of chlorhexidine pretreatment on bond strength durability of caries-affected dentin over 2-year aging in artificial saliva and under simulated intrapulpal pressure. Oper Dent. 2011;36(6):649-60. https://doi.org/10.2341/11-018-L

101. Manfro AR, Reis A, Loguercio AD, Imparato JC, Raggio DP. Effect of different concentrations of chlorhexidine on bond strength of primary dentin. Pediatr Dent. 2012;34(2):e11-5.

102. Zhou J, Tan J, Chen L, Li D, Tan Y. The incorporation of chlorhexidine in a two-step self-etching adhesive preserves dentin bond in vitro. J Dent. 2009;37(10):807-12. https://doi.org/10.1016/i.jdent.2009.06.011

103. Yiu CK, Hiraishi N, Tay FR, King NM. Effect of chlorhexidine incorporation into dental adhesive resin on durability of resin-dentin bond. J Adhes Dent. 2012;14(4):355-62. https://doi.org/10.3290/i.jad.a25674

104. Stanislawczuk R, Pereira F, Muñoz MA, Luque I, Farago PV, Reis $A$ et al. Effects of chlorhexidine-containing adhesives on the durability of resin-dentine interfaces. J Dent. 2014;42(1):39-47. https://doi.org/10.1016/i.jdent.2013.11.002

105. Loguercio AD, Hass V, Gutierrez MF, Luque-Martinez IV, Szezs A, Stanislawczuk R et al. Five-year Effects of chlorhexidine on the in vitro durability of resin/dentin interfaces. J Adhes Dent. 2016;18(1):35-42. https://doi.org/10.3290/i.jad.a35514

106. Carrilho MR, Carvalho RM, Sousa EN, Nicolau J, Breschi L, Mazzoni A et al. Substantivity of chlorhexidine to human dentin. Dent Mater. 2010;26(8):779-85. https://doi.org/10.1016/i.dental.2010.04.002

107. Zhou J, Tan J, Yang X, Cheng C, Wang X, Chen L. Effect of chlorhexidine application in a self-etching adhesive on the immediate resin-dentin bond strength. J Adhes Dent. 2010;12(1):27-31. https://doi.org/10.3290/i.jad.a17543

108. Zhou J, Tan J, Yang X, Xu X, Li D, Chen L. MMP-inhibitory effect of chlorhexidine applied in a self-etching adhesive. J Adhes Dent. 2011;13(2):111-5. https://doi.org/10.3290/i.jad.a18783

109. Pallan S, Furtado Araujo MV, Cilli R, Prakki A. Mechanical properties and characteristics of developmental copolymers incorporating catechin or chlorhexidine. Dent Mater. 2012;28(6):687-94. https://doi.org/10.1016/i.dental.2012.03.003

110. Abu Nawareg M, Elkassas D, Zidan A, Abuelenain D, Abu Haimed T, Hassan AH et al. Is chlorhexidine-methacrylate as effective as chlorhexidine digluconate in preserving resin dentin interfaces? J Dent. 2016;45:7-13. https://doi.org/10.1016/i.ident.2015.11.002 
111. Gendron R, Grenier D, Sorsa T, Mayrand D. Inhibition of the activities of matrix metalloproteinases 2,8 , and 9 by chlorhexidine. Clin Diagn Lab Immunol. 1999;6(3):437-9.

112. Moon PC, Weaver J, Brooks CN. Review of matrix metalloproteinases' effect on the hybrid dentin bond layer stability and chlorhexidine clinical use to prevent bond failure. Open Dent J. 2010;4(1):147-52. https://doi.org/10.2174/1874210601004010147

113. Hannas AR, Pereira JC, Granjeiro JM, Tjäderhane $L$. The role of matrix metalloproteinases in the oral environment. Acta Odontol Scand. 2007;65(1):1-13. https://doi.org/10.1080/00016350600963640

114. Tezvergil-Mutluay A, Agee KA, Hoshika T, Carrilho M,

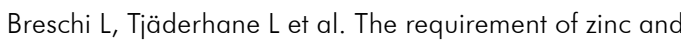
calcium ions for functional MMP activity in demineralized dentin matrices. Dent Mater. 2010;26(11):1059-67. https://doi.org/10.1016/j.dental.2010.07.006

115. Sabatini C, Kim JH, Ortiz Alias P. In vitro evaluation of benzalkonium chloride in the preservation of adhesive interfaces. Oper Dent. 2014;39(3):283-90. https://doi.org/10.2341/13-131-LR

116. Breschi L. Chlorhexidine application to stabilize the adhesive interface: why and how? J Adhes Dent. 2013;15(5):492. https://doi.org 10.3290/i.jad.a32067

117. Nishitani Y, Yoshiyama M, Wadgaonkar B, Breschi L, Mannello F, Mazzoni A et al. Activation of gelatinolytic/collagenolytic activity in dentin by self-etching adhesives. Eur J Oral Sci. 2006;114(2):160-6. https://doi.org/10.1111/j.1600-0722.2006.00342.x

118. Zheng P, Zaruba M, Attin T, Wiegand A. Effect of different matrix metalloproteinase inhibitors on microtensile bond strength of an etch-and-rinse and a self-etching adhesive to dentin. Oper Dent. 2015;40(1):80-6. https://doi.org/10.2341/13-162-L

119. Gunaydin Z, Yazici AR, Cehreli ZC. In vivo and in vitro effects of chlorhexidine pretreatment on immediate and aged dentin bond strengths. Oper Dent. 2016;41(3):258-67. https://doi.org/10.2341/14-231-C

120. Brackett WW, Tay FR, Brackett MG, Dib A, Sword RJ, Pashley DH. The effect of chlorhexidine on dentin hybrid layers in vivo. Oper Dent. 2007;32(2):107-11. https://doi.org/10.2341/06-55

121. Dutra-Correa M, Saraceni CH, Ciaramicoli MT, Kiyan VH, Queiroz CS. Effect of chlorhexidine on the 18-month clinical performance of two adhesives. J Adhes Dent. 2013;15(3):287-92. https://doi.org/10.3290/i.jad.a29533

122. Sartori N, Stolf SC, Silva SB, Lopes GC, Carrilho $M$. Influence of chlorhexidine digluconate on the clinical performance of adhesive restorations: a 3-year follow-up. J Dent. 2013;41(12):1188-95. https://doi.org/10.1016/i.jdent.2013.09.004

123. Araújo MS, Souza LC, Apolonio FM, Barros LO, Reis A, Loguercio AD et al. Two-year clinical evaluation of chlorhexidine incorporation in two-step self-etch adhesive. J Dent. 2015;43(1):140-8.

https://doi.org/10.1016/i.jdent.2014.07.010

124. Kanca J 3rd. One step bond strength to enamel and dentin. Am J Dent. 1997;10(1):5-8.

125. Tezvergil-Mutluay A, Mutluay MM, Gu LS, Zhang K, Agee KA, Carvalho RM et al. The anti-MMP activity of benzalkonium chloride. J Dent. 2011;39(1):57-64. https://doi.org/10.1016/i.jdent.2010.10.003

126. Sabatini C, Patel SK. Matrix metalloproteinase inhibitory properties of benzalkonium chloride stabilizes adhesive interfaces. Eur J Oral Sci. 2013;121(6):610-6. https://doi.org/10.1111/eos.12089

127. Sabatini C, Pashley DH. Mechanisms regulating the degradation of dentin matrices by endogenous dentin proteases and their role in dental adhesion: a review. Am J Dent. 2014;27(4):203-14.

128. Lauhio A, Salo T, Tiäderhane L, Lähdevirta J, Golub LM, Sorsa T. Tetracyclines in treatment of rheumatoid arthritis. Lancet. 1995;346(8975):645-6. https://doi.org/10.1016/S0140-6736(95)91484-6

129. Sulkala M, Wahlgren J, Larmas M, Sorsa T, Teronen O, Salo T et al. The effects of MMP inhibitors on human salivary MMP activity and caries progression in rats. J Dent Res. 2001;80(6):1545-9. https://doi.org/10.1177/00220345010800061301

130. Osorio R, Yamauti M, Osorio E, Ruiz-Requena ME, Pashley DH, Tay FR et al. Zinc reduces collagen degradation in demineralized human dentin explants. J Dent. 2011;39(2):148-53. https://doi.org/10.1016/i.jdent.2010.11.005

131. De Munck J, Van den Steen PE, Mine A, Van Landuyt KL, Poitevin A, Opdenakker G et al. Inhibition of enzymatic degradation of adhesivedentin interfaces. J Dent Res. 2009;88(12):1101-6. https://doi.org/10.1177/0022034509346952

132. Almahdy A, Koller G, Sauro S, Bartsch JW, Sherriff M, Watson TF et al. Effects of MMP inhibitors incorporated within dental adhesives. J Dent Res. 2012;91(6):605-11. https://doi.org/10.1177/0022034512446339

133. Garbisa S, Sartor L, Biggin S, Salvato B, Benelli R, Albini A. Tumor gelatinases and invasion inhibited by the green tea flavanol epigallocatechin-3-gallate. Cancer. 2001;91(4):822-32. https://doi.org/10.1002/10970142(20010215)91:4<822::AID-CNCR1070>3.0.CO;2-G

134. Magalhães AC, Wiegand A, Rios D, Hannas A, Attin T, Buzalaf MA. Chlorhexidine and green tea extract reduce dentin erosion and abrasion in situ. J Dent. 2009;37(12):994-8. https://doi.org/10.1016/i.jdent.2009.08.007

135. Torii Y, Hikasa R, Iwate S, Oyama F, Itou K, Yoshiyama M. Effect of EDTA conditioning on bond strength to bovine dentin promoted by four current adhesives. Am J Dent. 2003;16(6):395-400. 
136. Jacques P, Hebling J. Effect of dentin conditioners on the microtensile bond strength of a conventional and a self-etching primer adhesive system. Dent Mater. 2005;21(2):103-9. https://doi.org/10.1016/i.dental.2003.12.004

137. Sauro S, Mannocci F, Toledano M, Osorio R, Pashley DH, Watson TF. EDTA or $\mathrm{H} 3 \mathrm{PO} 4 / \mathrm{NaOCl}$ dentine treatments may increase hybrid layers' resistance to degradation: a microtensile bond strength and confocal-micropermeability study. J Dent. 2009;37(4):279-88. https://doi.org/10.1016/i.jdent.2008.12.002

138. Toledano M, Yamauti M, Osorio E, Osorio R. Zinc-inhibited MMP-mediated collagen degradation after different dentine demineralization procedures. Caries Res. 2012a;46(3):201-7. https://doi.org/10.1159/000337315

139. Toledano M, Yamauti M, Ruiz-Requena ME, Osorio R. A ZnO-doped adhesive reduced collagen degradation favouring dentine remineralization. J Dent. 2012b;40(9):756-65. https://doi.org/10.1016/i.jdent.2012.05.007

140. Sauro S, Osorio R, Osorio E, Watson TF, Toledano M. Novel light-curable materials containing experimental bioactive micro-fillers remineralise mineral-depleted bonded-dentine interfaces. J Biomater Sci Polym Ed. 2013;24(8):940-56. https://doi.org/10.1080/09205063.2012.727377

141. Toledano M, Sauro S, Cabello I, Watson T, Osorio R. A $\mathrm{Zn}$-doped etch-and-rinse adhesive may improve the mechanical properties and the integrity at the bonded-dentin interface. Dent Mater. 2013;29(8):e142-52. https://doi.org/10.1016/i.dental.2013.04.024

142. Donmez N, Belli S, Pashley DH, Tay FR. Ultrastructural correlates of in vivo/in vitro bond degradation in self-etch adhesives. J Dent Res. 2005;84(4):355-9. https://doi.org/10.1177/154405910508400412

143. Erhardt MC, Toledano M, Osorio R, Pimenta LA. Histomorphologic characterization and bond strength evaluation of caries-affected dentin/resin interfaces: effects of long-term water exposure. Dent Mater. 2008;24(6):786-98. https://doi.org/10.1016/j.dental.2007.09.007

144. Tiäderhane L, Mehtälä P, Scaffa P, Vidal C, Pääkkönen V, Breschi $L$ et al. The effect of dimethyl sulfoxide (DMSO) on dentin bonding and nanoleakage of etch-and-rinse adhesives. Dent Mater. 2013;29(10):1055-62. https://doi.org/10.1016/i.dental.2013.07.014

145. Mehtälä P, Agee K, Breschi L, Pashley DH, Tiäderhane L. Proprietary solvent enhances dentin wettability. Dent Mater. 2010;26 Suppl 1:e12-3. https://doi.org/10.1016/i.dental.2010.08.033

146. Marren K. Dimethyl sulfoxide: an effective penetration enhancer for topical administration of NSAIDs. Phys Sportsmed. 2011;39(3):75-82. https://doi.org/10.3810/psm.2011.09.1923

147. Tay FR, Pashley DH. Water treeing: a potential mechanism for degradation of dentin adhesives. Am J Dent 2003,16(1):6-12.
148. Reis A, Albuquerque M, Pegoraro M, Mattei G, Baver JR, Grande RH et al. Can the durability of one-step self-etch adhesives be improved by double application or by an extra layer of hydrophobic resin? J Dent. 2008 May;36(5):309-15. https://doi.org/10.1016/i.jdent.2008.01.018

149. Sezinando A, Luque-Martinez I, Muñoz MA, Reis A, Loguercio AD, Perdigão J. Influence of a hydrophobic resin coating on the immediate and 6-month dentin bonding of three universal adhesives. Dent Mater. 2015 Oct;31(10):e236-46. https://doi.org/10.1016/i.dental.2015.07.002

150. Muñoz MA, Sezinando A, Luque-Martinez I, Szesz AL, Reis $A$, Loguercio AD et al. Influence of a hydrophobic resin coating on the bonding efficacy of three universal adhesives. J Dent. 2014;42(5):595-602. https://doi.org/10.1016/i.jdent.2014.01.013

151. Silva SMA, Carrilho MR, Marquezini Junior L, Garcia FC, Manso AP, Alves MC et al. Effect of an additional hydrophilic versus hydrophobic coat on the quality of dentinal sealing provided by two-step etch-and-rinse adhesives. J Appl Oral Sci. 2009;17(3):184-9. https://doi.org/10.1590/S1678-77572009000300010

152. Albuquerque M, Pegoraro M, Mattei G, Reis A, Loguercio AD. Effect of double-application or the application of a hydrophobic layer for improved efficacy of one-step self-etch systems in enamel and dentin. Oper Dent. 2008;33(5):564-70. https://doi.org/10.2341/07-145

153. Frankenberger R, Lohbauer $U$, Roggendorf MJ, Naumann $M$, Taschner M. Selective enamel etching reconsidered: better than etch-and-rinse and self-etch? J Adhes Dent. 2008;10(5):339-44.

154. Kanemura N, Sano H, Tagami J. Tensile bond strength to and SEM evaluation of ground and intact enamel surfaces. J Dent. 1999;27(7):523-30. https://doi.org/10.1016/S0300-5712(99)00008-1

155. Pashley DH, Tay FR. Aggressiveness of contemporary self-etching adhesives. Part II: etching effects on unground enamel. Dent Mater. 2001;17(5):430-44. https://doi.org/10.1016/S0109-5641(00)00104-4

156. Muñoz MA, Luque I, Hass V, Reis A, Loguercio AD, Bombarda $\mathrm{NH}$. Immediate bonding properties of universal adhesives to dentine. J Dent. 2013;41(5):404-11. https://doi.org/10.1016/i.jdent.2013.03.001

157. Van Landuyt KL, Kanumilli P, De Munck J, Peumans M, Lambrechts P, Van Meerbeek B. Bond strength of a mild selfetch adhesive with and without prior acid-etching. J Dent. 2006;34(1):77-85. https://doi.org/10.1016/i.jdent.2005.04.001

158. Barkmeier WW, Erickson RL, Kimmes NS, Latta MA, Wilwerding TM. Effect of enamel etching time on roughness and bond strength. Oper Dent. 2009;34(2):217-22. https://doi.org/10.2341/08-72

159. Watanabe T, Tsubota K, Takamizawa T, Kurokawa H, Rikuta $\mathrm{A}$, Ando $\mathrm{S}$ et al. Effect of prior acid etching on bonding durability of single-step adhesives. Oper Dent. 2008;33(4):426-33. https://doi.org/10.2341/07-110 
160. Erickson RL, Barkmeier WW, Latta MA. The role of etching in bonding to enamel: a comparison of self-etching and etch-and-rinse adhesive systems. Dent Mater. 2009;25(11):1459-67. https://doi.org/10.1016/i.dental.2009.07.002

161. Taschner M, Nato F, Mazzoni A, Frankenberger R, Krämer N, Di Lenarda $R$ et al. Role of preliminary etching for one-step self-etch adhesives. Eur J Oral Sci. 2010;118(5):517-24. https://doi.org/10.1111/j.1600-0722.2010.00769.x

162. Devarasa GM, Subba Reddy VV, Chaitra NL, Swarna YM. Self-etching adhesive on intact enamel, with and without pre-etching. Microsc Res Tech. 2012;75(5):650-4. https://doi.org/10.1002/jemt.21106

163. Li N, Nikaido T, Alireza S, Takagaki T, Chen JH, Tagami J. Phosphoric acid-etching promotes bond strength and formation of acid-base resistant zone on enamel. Oper Dent. 2013;38(1):82-90. https://doi.org/10.2341/11-422-L

164. Mena-Serrano A, Kose C, De Paula EA, Tay LY, Reis A, Loguercio $A D$ et al. A new universal simplified adhesive: 6-month clinical evaluation. J Esthet Restor Dent. 2013;25(1):55-69. https://doi.org/10.1111/jerd.12005

165. Moura SK, Pelizzaro A, Dal Bianco K, Goes MF, Loguercio $A D$, Reis $A$ et al. Does the acidity of self-etching primers affect bond strength and surface morphology of enamel? J Adhes Dent. 2006;8(2):75-83.

166. Perdigão J, Lopes MM, Gomes G. In vitro bonding performance of self-etch adhesives: II. ultramorphological evaluation. Oper Dent. 2008;33(5):534-49. https://doi.org/10.2341/07-133

167. Moura SK, Reis A, Pelizzaro A, Dal-Bianco K, Loguercio AD, Arana-Chavez VE et al. Bond strength and morphology of enamel using self-etching adhesive systems with different acidities. J Appl Oral Sci. 2009;17(4):315-25. https://doi.org/10.1590/S1678-77572009000400009

168. Cardenas AM, Siqueira F, Rocha J, Szesz AL, Anwar M, El-Askary F et al. Influence of conditioning time of universal adhesives on adhesive properties and enamel-etching pattern. Oper Dent. 2016;41(5):481-90. https://doi.org/10.2341/15-213-L

169. Mine A, De Munck J, Cardoso MV, Van Landuyt KL, Poitevin A, Kuboki T et al. Enamel-smear compromises bonding by mild self-etch adhesives. J Dent Res. 2010;89(12):1505-9. https://doi.org/10.1177/0022034510384871

170. Goes MF, Shinohara MS, Freitas MS. Performance of a new one-step multi-mode adhesive on etched vs non-etched enamel on bond strength and interfacial morphology. J Adhes Dent. 2014;16(3):243-50. https://doi.org/10.3290/i.jad.a32033

171. Velasquez LM, Sergent RS, Burgess JO, Mercante DE. Effect of placement agitation and placement time on the shear bond strength of 3 self-etching adhesives. Oper Dent. 2006;31(4):426-30. https://doi.org/10.2341/05-52

172. Rotta M, Bresciani P, Moura SK, Grande RH, Hilgert LA, Baratieri $L N$ et al. Effects of phosphoric acid pretreatment and substitution of bonding resin on bonding effectiveness of selfetching systems to enamel. J Adhes Dent. 2007;9 (6):537-45.
173. Erickson RL, Barkmeier WW, Kimmes NS. Bond strength of self-etch adhesives to pre-etched enamel. Dent Mater. 2009;25(10):1187-94. https://doi.org/10.1016/i.dental.2009.04.004

174. Batra C, Nagpal R, Tyagi SP, Singh UP, Manuja N. In vitro bonding effectiveness of three different one-step self-etch adhesives with additional enamel etching. J Investig Clin Dent. 2014;5(3):226-36. https://doi.org/10.1111/jicd.12039

175. Szesz A, Parreiras S, Reis A, Loguercio A. Selective enamel etching in cervical lesions for self-etch adhesives: a systematic review and meta-analysis. J Dent. 2016;53:1-11. https://doi.org/10.1016/i.jdent.2016.05.009

176. Loguercio AD, Muñoz MA, Luque-Martinez I, Hass V, Reis A, Perdigão J. Does active application of universal adhesives to enamel in self-etch mode improve their performance? J Dent. 2015; 43(9):1060-70. https://doi.org/10.1016/i.jdent.2015.04.005

177. Peumans M, De Munck J, Van Landuyt KL, Poitevin A, Lambrechts $P$, Van Meerbeek B. Eight-year clinical evaluation of a 2-step self-etch adhesive with and without selective enamel etching. Dent Mater. 2010;26(12):1176-84. https://doi.org/10.1016/j.dental.2010.08.190

178. Bittencourt DD, Ezecelevski IG, Reis A, Van Dijken JW, Loguercio AD. An 18-months' evaluation of self-etch and etch \& rinse adhesive in non-carious cervical lesions. Acta Odontol Scand. 2005;63(3):173-8. https://doi.org/10.1080/00016350510019874

179. Loguercio AD, Bittencourt DD, Baratieri LN, Reis A. A 36-month evaluation of self-etch and etch-and-rinse adhesives in noncarious cervical lesions. J Am Dent Assoc. 2007;138(4):50714. https://doi.org/10.14219/jada.archive.2007.0204

180. Perdigão J, Dutra-Corrêa M, Saraceni CH, Ciaramicoli MT, Kiyan VH, Queiroz CS. Randomized clinical trial of four adhesion strategies: 18-month results. Oper Dent. 2012;37(1):3-11. https://doi.org/10.2341/11-222-C

181. Moosavi H, Kimyai S, Forghani M, Khodadadi R. The clinical effectiveness of various adhesive systems: an 18-month evaluation. Oper Dent. 2013;38(2):134-41. https://doi.org/10.2341/12-110-CR

182. Ozer F, Blatz MB. Self-etch and etch-and-rinse adhesive systems in clinical dentistry. Compend Contin Educ Dent. 2013;34(1):12-4

183. Goh KL, Meakin JR, Aspden RM, Hukins DW. Stress transfer in collagen fibrils reinforcing connective tissues: effects of collagen fibril slenderness and relative stiffness. J Theor Biol. 2007;245(2):305-11. https://doi.org/10.1016/i.jtbi.2006.10.008

184. Bedran-Russo AK, Castellan CS, Shinohara MS, Hassan L, Antunes A. Characterization of biomodified dentin matrices for potential preventive and reparative therapies. Acta Biomaterialia 2011;7(4):1735-41. https://doi.org/10.1016/j.actbio.2010.12.013

185. Saito M, Marumo K. Collagen cross-links as a determinant of bone quality: a possible explanation for bone fragility in aging, osteoporosis, and diabetes mellitus. Osteoporos Int. 2010;21(2):195-214. https://doi.org/10.1007/s00198-009-1066-z 
186. Takaluoma K, Lantto J, Myllyhariu J. Lysyl hydroxylase 2 is a specific telopeptide hydroxylase, while all three isoenzymes hydroxylate collagenous sequences. Matrix Biol. 2007;26(5):396-403. https://doi.org/10.1016/i.matbio.2007.01.002

187. Knott L, Bailey AJ. Collagen cross-links in mineralizing tissues: a review of their chemistry, function, and clinical relevance. Bone 1998; 22(3):181-7. https://doi.org/10.1016/S8756-3282(97)00279-2

188. Reiser K, McCormick RJ, Rucker RB. Enzymatic and non-enzymatic cross-linking of collagen and elastin. FASEB J 1992;6(7):2439-49.

189. Rivera EM, Yamauchi M. Site comparisons of dentine collagen cross-links from extracted human teeth, Arch Oral Biol. 1993;38(7):541-6. https://doi.org/10.1016/0003-9969(93)90118-6

190. Orgel JP, Irving TC, Miller A, Wess TJ. Microfibrillar structure of type I collagen in situ, Proc. Natl. Acad. Sci. U. S. A. 2006;103(24);9001-5. https://doi.org/10.1073/pnas.0502718103

191. Bertassoni LE, Orgel JP, Antipova O, Swain MV. The dentin organic matrix - limitations of restorative dentistry hidden on the nanometer scale. Acta Biomater. 2012;8(7):2419-33. Duplicata da 50

192. Vidal CM, Zhu W, Manohar S, Aydin B, Keiderling TA, Messersmith PB et al. Collagen-collagen interactions mediated by plant-derived proanthocyanidins: A spectroscopic atomic force microscopy study. Acta Biomater. 2016;41(41):110-8. https://doi.org/10.1016/j.actbio.2016.05.026

193. Vidal CM, Leme AA, Aguiar TR, Phansalkar R, Nam JW, Bisson $\mathrm{J}$ et al. Mimicking the hierarchical functions of dentin collagen cross-links with plant derived phenols and phenolic acids. Langmuir. 2014;30(49):14887-93. https://doi.org/10.1021/la5034383

194. Han B, Jaurequi J, Tang BW, Nimni ME. Proanthocyanidin: a natural crosslinking reagent for stabilizing collagen matrices. J Biomed Mater Res A. 2003;65(1):118-24. https://doi.org/10.1002/jbm.a.10460

195. Sung HW, Chang WH, Ma CY, Lee MH. Crosslinking of biological tissues using genipin and/or carbodiimide. J Biomed Mater Res A. 2003;64(3):427-38. https://doi.org/10.1002/jbm.a.10346

196. Bedran-Russo AK, Pauli GF, Chen SN, McAlpine J, Castellan CS, Phansalkar RS et al. Dentin biomodification: strategies, renewable resources and clinical applications. Dent Mater. 2014;30(1):62-76. https://doi.org/10.1016/i.dental.2013.10.012

197. Foote CS. Mechanisms of photosensitized oxidation. There are several different types of photosensitized oxidation which may be important in biological systems. Science 1968;162(3857):963-70. https://doi.org/10.1126/science.162.3857.963

198. Xu C, Wang Y. Cross-linked demineralized dentin maintains its mechanical stability when challenged by bacterial collagenase. J Biomed Mater Res B Appl Biomater. 2011;96(2):242-8. https://doi.org/10.1002/jbm.b.31759
199. Bedran-Russo AK, Pereira PN, Duarte WR, Drummond JL, Yamauchi M. Application of crosslinkers to dentin collagen enhances the ultimate tensile strength. J Biomed Mater Res B Appl Biomater. 2007;80(1):268-72. https://doi.org/10.1002/ibm.b.30593

200. Bedran-Russo AK, Vidal CM, Santos PH, Castellan CS. Long-term effect of carbodiimide on dentin matrix and resin-dentin bonds. J Biomed Mater Res B Appl Biomater 2010;94(1):250-5. https://doi.org/10.1002/jbm.b.31649

201. Tezvergil-Mutluay A, Mutluay MM, Agee KA, Seseogullari-Dirihan R, Hoshika T, Cadenaro M et al. Carbodiimide cross-linking inactivates soluble and matrix-bound MMPs, in vitro. J Dent Res. 2012;91(2):192-6. https://doi.org/10.1177/0022034511427705

202. Mazzoni A, Angeloni V, Apolonio FM, Scotti N, Tiäderhane L, Tezvergil-Mutluay A et al. Effect of carbodiimide (EDC) on the bond stability of etch-and-rinse adhesive systems. Dent Mater. 2013;29(10):1040-7. https://doi.org/10.1016/j.dental.2013.07.010

203. Sung HW, Chang Y, Chiu CT, Chen CN, Liang HC. Crosslinking characteristics and mechanical properties of a bovine pericardium fixed with a naturally occurring crosslinking agent. J Biomed Mater Res. 1999;47(2):116-26. https://doi.org/10.1002/(SICI)10974636(199911)47:2<116::AID-JBM2>3.0.CO;2-J

204.Al-Ammar A, Drummond JL, Bedran-Russo AK. The use of collagen cross-linking agents to enhance dentin bond strength. J Biomed Mater Res B Appl Biomater. 2009;91(1):419-24. https://doi.org/10.1002/jbm.b.31417

205. Cheng H, Caterson B, Yamauchi M. Identification and immunolocalization of chondroitin sulfate proteoglycans in tooth cementum. Connect Tissue Res. 1999;40(1):37-47. https://doi.org/10.3109/03008209909005276

206. Castellan CS, Pereira PN, Viana G, Chen SN, Pauli GF, Bedran-Russo AK. Solubility study of phytochemical cross-linking agents on dentin stiffness. J Dent. 2010;38(5):431-6. https://doi.org/10.1016/i.jdent.2010.02.002

207. Castellan CS, Bedran-Russo AK, Karol S, Pereira PN. Long-term stability of dentin matrix following treatment with various natural collagen cross-linkers. J Mech Behav Biomed Mater. 2011;4(7):1343-50. https://doi.org/10.1016/i.jmbbm.2011.05.003

208. Singh H, Kapoor P, Dhillon J, Kaur M. Evaluation of three different concentrations of Chlorhexidine for their substantivity to human dentin. Indian J Dent. 2014;5(4):199-201. https://doi.org/10.4103/0975-962X.144726

209. Chiaraputt S, Mai S, Huffman BP, Kapur R, Agee KA, Yiu CK et al. Changes in resin-infiltrated dentin stiffness after water storage. J Dent Res. 2008;87(7):655-60. https://doi.org/10.1177/154405910808700704

210. Nishitani Y, Yoshiyama M, Donnelly AM, Agee KA, Sword J, Tay FR et al. Effects of resin hydrophilicity on dentin bond strength. J Dent Res. 2006;85(11):1016-21. https://doi.org/10.1177/154405910608501108 
211. Sadek FT, Pashley DH, Nishitani Y, Carrilho MR, Donnelly A, Ferrari $\mathrm{M}$ et al. Application of hydrophobic resin adhesives to acid-etched dentin with an alternative wet bonding technique. J Biomed Mater Res A. 2008;84(1):19-29. https://doi.org/10.1002/jbm.a.31290

212. Hosaka K, Nishitani Y, Tagami J, Yoshiyama M, Brackett WW, Agee KA et al. Durability of resin-dentin bonds to water- vs. ethanol-saturated dentin. J Dent Res. 2009;88(2):146-51. https://doi.org/10.1177/0022034508328910

213. Pashley EL, Zhang Y, Lockwood PE, Rueggeberg FA, Pashley DH. Effects of HEMA on water evaporation from water-HEMA mixtures. Dent Mater. 1998;14(1):6-10. https://doi.org/10.1016/S0109-5641(98)00003-7

214. Sadek FT, Pashley DH, Nishitani Y, Carrilho MR, Donnelly A, Ferrari $\mathrm{M}$ et al. Application of hydrophobic resin adhesives to acid-etched dentin with an alternative wet bonding technique. J Biomed Mater Res A. 2007;84(1):19-29. https//doi.org/10.1002/jbm.a.31290

215. Pashley DH, Tay FR, Carvalho RM, Rueggeberg FA, Agee KA, Carrilho $\mathrm{M}$ et al. From dry bonding to water-wet bonding to ethanol-wet bonding: a review of the interactions between dentin matrix and solvated resins using a macromodel of the hybrid layer. Am J Dent. 2007;20(1):7-20.

216. Tay FR, Pashley DH, Kapur RR, Carrilho MR, Hur YB, Garrett LV et al. Bonding BisGMA to dentin: a proof of concept for hydrophobic dentin bonding. J Dent Res. 2007;86(11):1034-9. https://doi.org/10.1177/154405910708601103
217. Tay FR, Gwinnett JA, Wei SH. Micromorphological spectrum from overdrying to overwetting acid-conditioned dentin in water-free acetone-based, single-bottle primer/adhesives. Dent Mater. 1996;12(4):236-244. https://doi.org/10.1016/S0109-5641(96)80029-7

218. Wang Y, Spencer P, Hager C, Bohaty B. Comparison of interfacial characteristics of adhesive bonding to superficial versus deep dentine using SEM and staining techniques. J Dent. 2006;34(1):26-34. https://doi.org/10.1016/i.jdent.2005.03.004

219. Ye Q, Park JG, Topp E, Wang Y, Misra A, Spencer P. In vitro performance of nano-heterogeneous dentin adhesive. J Dent Res. 2008;87(9):829-33. https://doi.org/10.1177/154405910808700911

220. Becker TD, Agee KA, Joyce AP, Rueggeberg FA, Borke JL, Waller JL et al. Infiltration/evaporation-induced shrinkage of demineralized dentin by solvated model adhesives. J Biomed Mater Res B Appl Biomater. 2007;80(1):156-65. https://doi.org/10.1002/ibm.b.30580

221. Sauro S, Watson TF, Mannocci F, Miyake K, Huffman BP, Tay FR et al. Two-photon laser confocal microscopy of micropermeability of resin-dentin bonds made with water or ethanol wet bonding. J Biomed Mater Res B Appl Biomater. 2009;90(1):327-37. https://doi.org/10.1002/jbm.b.31290

222. Sadek FT, Braga RR, Muench A, Liu Y, Pashley DH, Tay FR. Ethanol wet-bonding challenges current anti-degradation strategy. J Dent Res. 2010;89(12):1499-504. https://doi.org/10.1177/0022034510385240 